\title{
ソールプレート周辺にき裂を有する鋼橋I桁 端部のせん断耐荷力特性に関する基礎的研究
}

\author{
金 仁浩 ${ }^{1} \cdot$ 山口隆司 ${ }^{2} \cdot$ 北田俊行 $^{3} \cdot$ 中村智昭 ${ }^{4}$ \\ 1 学生員 大阪市立大学大学院工学研究科後期博士課程 3 年（干 558-8585 大阪市住吉区杉本 3-3-138） \\ E-mail: chokopie@brdg.civil.eng.osaka-cu.ac.jp \\ 2 正会員 大阪市立大学大学院准教授（干558-8585 大阪市住吉区杉本 3-3-138） \\ E-mail: yamaguti@civil.eng.osaka-cu.ac.jp \\ 3 正会員 大阪市立大学大学院教授（干558-8585 大阪市住吉区杉本 3-3-138） \\ E-mail:kitada@civil.eng.osaka-cu.ac.jp \\ 4 正会員 (株) 横河工事 （广550-0004 大阪市西区勒本町 1-4-12） \\ E-mail: nakamuto@yokogawa-kouji.co.jp
}

\begin{abstract}
本研究では, せん断力が支配的な鋼橋I桁端部に注目し, 支承上のソールプレート周辺で発生し, 下フラ ンジ全幅, あるいは腹板にまで進展した疲労き裂を有する場合のせん断耐荷力特性を単調載荷実験と弾塑 性有限変位解析により検討することを目的としている。単調載荷実験では，き裂の部位と長さが異なる3 体の実験供試体に対して載荷実験を行い，き裂が生じた桁端部の残存せん断耐荷力を調べている。次に， 腹板に進展したき裂の長さをパラメータとした弾塑性有限変位解析を行い, き裂長さと残存せん断耐荷力 特性との関係について検討を行っている. その結果, き裂長さが残存せん断座屈荷重に影響し, き裂長さ により崩壊メカニズムが異なること, 本研究の対象とした範囲では終局荷重である残存せん断耐荷力には あまり影響しないことを明らかにしている。
\end{abstract}

Key Words : plate girder end, sole plate, fatigue crack, residual shear strength, steel bridge

\section{1. はじめに}

近年，既設鋼橋において，供用年数の経過，通過交通 量の増加，および車軸重量の増大に伴い，疲労損傷の発 生が大きな問題として取り上げられるようになっている.

このような損傷事例の 1 つに, 鋼橋桁端部の支承ソー ルプレート溶接部に発生する疲労き裂が挙げられる. 典 型的なき裂発生事例を図-1 に示寸. 我国の道路橋では,

一般的に, ソールプレートは, 板厚が 22〜 25mm の鋼板 を用い，下フランジにその全周をすみ肉溶接して取付け られている. 図-1 に示寸ように，鋼析支承ソールプレー 卜溶接部に発生する疲労き裂の多くは下フランジ下面の ソールプレート前面すみ肉溶接止端部の腹板直下付近か ら発生している。これらの事例の中には，すみ肉溶接の 止端に沿って進展したき裂が下フランジを全幅貫通した 後, 腹板にまで進展した例もある.ソールプレート溶接 部付近における疲労損傷に関しては, 疲労き裂の発生原 因の究明や桁端部の最適な構造詳細の検討を目的とした 調査・研究がこれまでに数多くなされ，様々な知見が明 らかにされている11-3).
しかし，疲労き裂が発見された時点において，鋼橋桁 端部がどれだけの残存せん断而何力を有しているのかと いう, 研究は多くない.

本研究では，鋼橋桁支承上ソールプレート溶接部付近 における疲労損傷の現状を踏まえ，疲労き裂進展後の桁 端部の終局せん断力特性やその座屈崩壊挙動を調べる基 礎資料の提供を目的として，ソールプレート周辺に模擬 的なき裂を含む鋼I桁端部をモデル化した供試体を製作

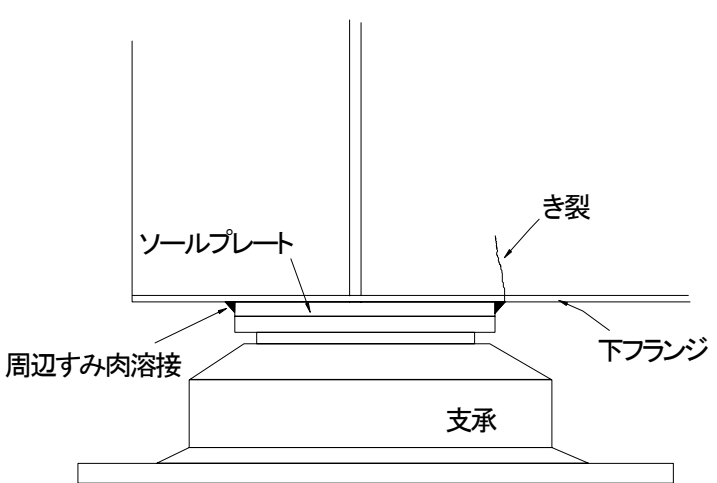

図-1ソールプレート周辺の代表的なき裂事例 ${ }^{4)}$ 
し，静的載荷実験を実施している，さらに，鋼橋桁支承 上ソールプレート溶接部付近における疲労き裂の大きさ とせん断而荷力との関係を定量的に評価するために，き 裂長さをパラメータとした弾塑性有限変位解析を行って いる.

\section{2. せん断耐荷力実験}

\section{（1）実験供試体}

実験供試体は，与える模擬き裂の有無とその長さとを パラメータとして 3 体製作した. 本実験ではせん断而渮 力とき裂との関係に主眼をおいていることから，実験供 試体は道路橋示方書の規定を満足した上で，せん断座屈 が支配的となるよう断面決定している，そのため，実構 造の構造諸元を縮尺したものではない.

実験供試体の名称, および与えたき裂の程度を表-1 に まとめている，実験供試体の形状寸法およびき裂位置を 図-2 に示寸．供試体に用いた鋼材はすべて SS400 材であ る. 端垂直補剛材および載荷点における垂直補剛材は下 フランジとそれぞれ，すみ肉溶接により接合されている. 写真-1には, 下フランジにき裂がある Type-II 供試体のき 裂周辺部の拡大写真を示している.

実験対象である Panel A(図-2 参照)のアスペクト比と

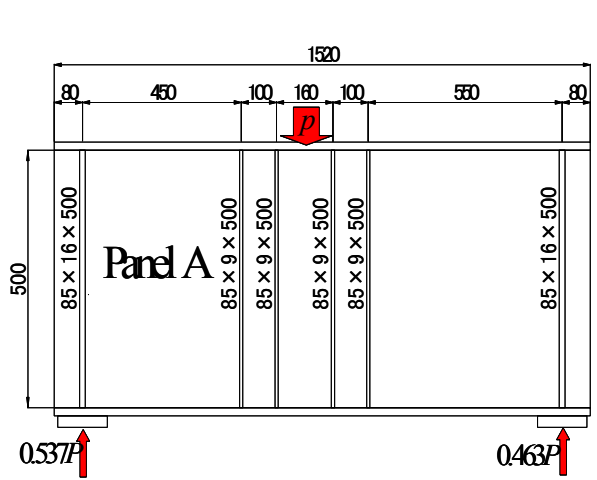

i) 側面図

(a) Type-I

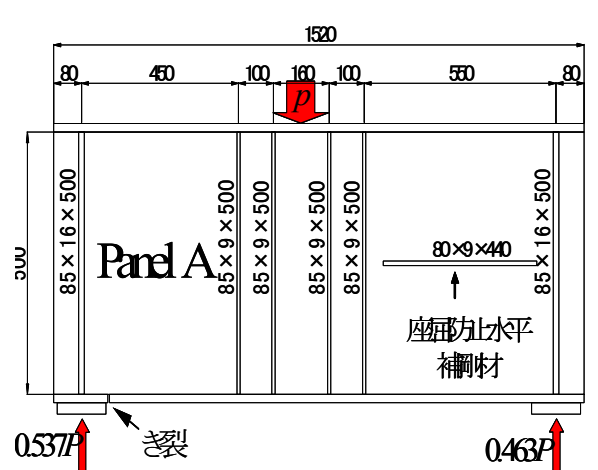

i) 側面図

(b) Type-II

ii) 断面図

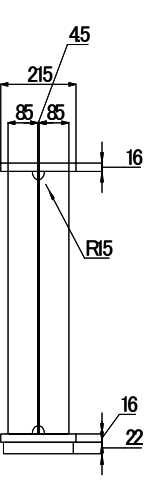

ii) 断面図
せん断座屈に対する幅厚比パラメータ $R_{\text {tw }}$ を表-2に示す. なお，すべての供試体の腹板厚の公称值は $4.5 \mathrm{~mm}$ で共通 である. 腹板のせん断座屈に対する幅厚比パラメータ (せ ん断座屈パラメータ) $R_{w}$ は，次式 $(1 \mathrm{a})^{5)}$ で与えられる.

$$
R_{\tau w}=\sqrt{\frac{\tau_{y}}{\tau_{c r}^{e}}}=\frac{h}{t_{w}} \sqrt{\frac{\sigma_{y}}{\sqrt{3} E} \frac{12\left(1-v^{2}\right)}{\pi^{2} \kappa_{s}}}
$$

ここに, $\tau_{c}^{e}$ : 弾性せん断座屈応力度, $b$ : 腹板高, $\tau_{y}$ : 降伏せ ん断応力度, $t_{w}$ : 腹板厚, $\sigma_{Y}$ : 降伏点, $v$ : ポアソン比, $E$ : ヤング係数である。

なお, 幅厚比パラメータと耐荷力の理論值の算定には, 実測值を用いている.

また，座屈係数 $\kappa_{S}$ は，次式(1b)より求められる.

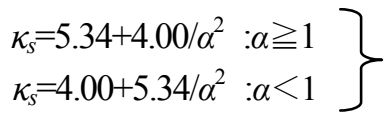

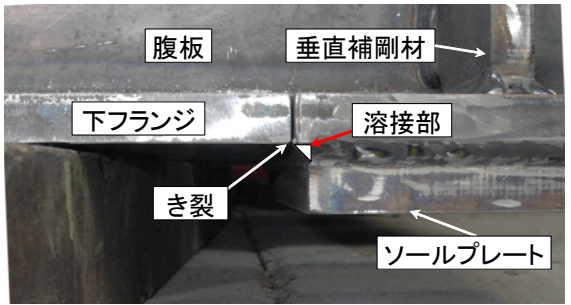

写真-1 き裂周辺の様子

表-1＼cjkstart実験供試体名と与えたき裂パターン

\begin{tabular}{|c|c||c|c|c|}
\hline \multirow{2}{*}{ 実験供試体名 } & \multicolumn{4}{|c|}{ き裂位置および長さ } \\
\cline { 2 - 5 } & 下フランジ & き裂長さ & ウェブ & き裂長さ \\
\hline Type-I & き裂なし & - & き裂なし & - \\
\hline Type-II & き裂あり & $215 \mathrm{~mm}$ (幅全域) & き裂なし & - \\
\hline Type-III & き裂あり & $215 \mathrm{~mm}$ (幅全域) & き裂あり & $20 \mathrm{~mm}$ \\
\hline
\end{tabular}

表-2＼cjkstart実験供試体腹板のせん断座屈パラメータ

\begin{tabular}{|c|c|c|}
\hline & アスペクト比 $\alpha$ & 幅厚比パラメータ $\mathrm{R}_{\mathrm{rw}}$ \\
\hline Panel A & 0.9 & 1.1 \\
\hline
\end{tabular}

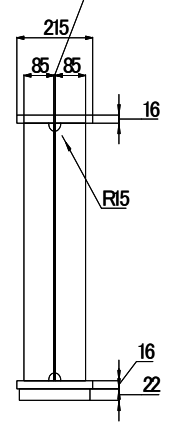

図-2 実験供試体の形状，寸法，およびき裂位置(寸法単位:mm) 
ここで, $\alpha$ はアスペクト比 $(a$ (腹板の幅 $) / b$ (腹板の高さ $))$ である.

下フランジの模擬き裂は, 下フランジと腹板とを溶接 する前に下フランジをレーザー切断機により 2 分割し, き裂幅（2mm）を残して，溶接することによって導入し た. 供試体 Type-III における腹板の模擬き裂は, 腹板とフ ランジとの溶接前にレーザー切断機により導入した.

\section{（2）実験方法}

\section{a）載荷方法}

図-3 (a)に示すように，載荷ばり上に供試体をセットし， $1,000 \mathrm{kN}$ 万能試験機により集中荷重 $P$ を供試体に載荷し 着目腹板パネルに所定のせん断力 $V$ を導入する. なお， せん断座屈が発生後も載荷を続け，作用集中荷重 $P$ が低 下するまで単調に載荷した. なお, 無次元化せん断力 $\left(S / S_{y}\right)$ と無次元化曲げモーメント $\left(M / M_{y}\right)$ の比は 1.34 である.

\section{b) 測定方法}

実験では載荷荷重 $P$, 腹板の面外方向変位，腹板表面 のひずみ，および下フランジの鉛直変位を測定した．測 定には多チャンネルのひずみ量を同時に測定できる多点 同時測定計測装置を用いた. 載荷荷重は図-3(a)に示すよ うにロードセルをセットして測定した．ひずみゲージの
貼付位置を図-4に示す.

3 軸ひずみゲージは, 着目腹板パネルの中央断面におけ る主ひずみの方向および腹板パネルの座屈挙動を調べる ために両面にゲージを貼付した. 2 軸ひずみゲージは着目 腹板パネルの対角方向に貼付し， 3 軸ひずみゲージととも に，斜張力場の位置と応力分布を明らかにすることを目 的としている.

腹板パネルがせん断座屈後, 斜張力場が発生し, 腹板 パネルが終局状態に至ると，腹板パネルは垂直補岡材と 上下フランジからなるラーメン構造でせん断力に抵抗す る. このラーメン構造に塑性崩壊機構が発生すると桁全 体が終局状態に至る，そこで，上下フランジの降伏が予 想される付近には 1 軸ひずみゲージを片面に貼付けるこ とを原則とし，フランジ片側の外縁のみ両面に貼付けて いる.

\section{（3）実験供試体材料の機械的性質と腹板パネルの初期た} わみ

a）材料の機械的性質

実験供試体に用いた鋼板の材料試験結果を表-3 に示す. また，その際に得られた鋼板材料の応力ーひずみ関係の一 例を図-5に示す.

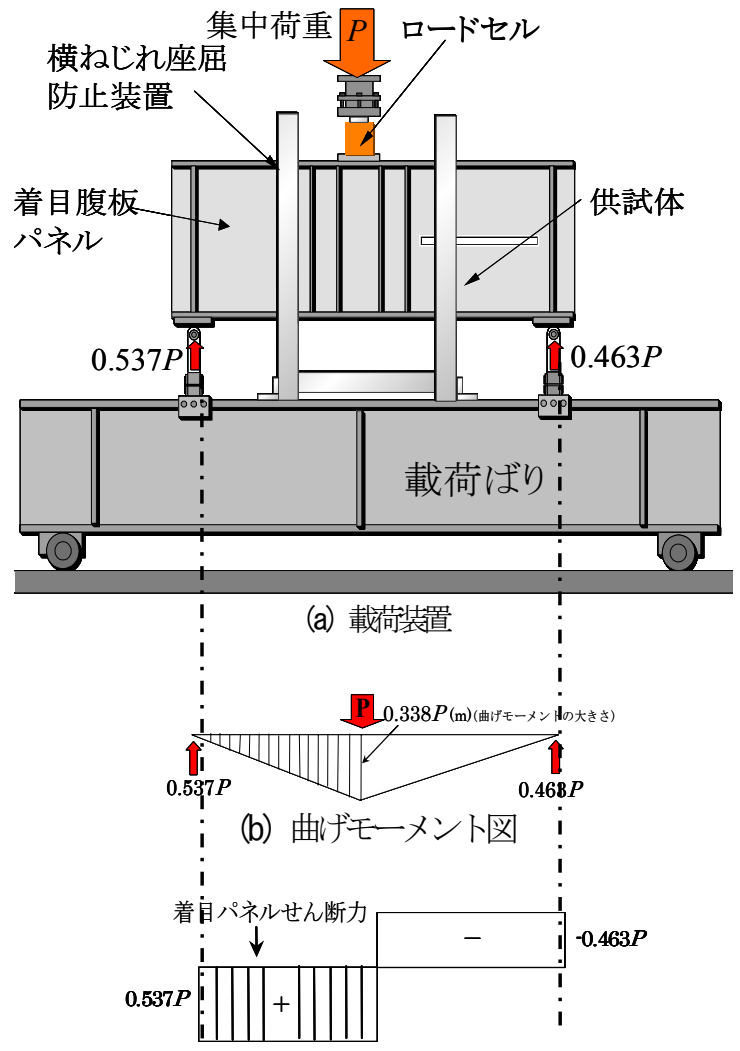

(c) せん断力図

図-3 載荷装置と断面力図

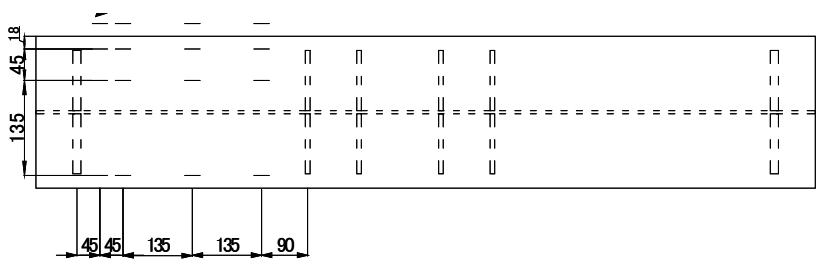

(a) 上フランジ(上面)

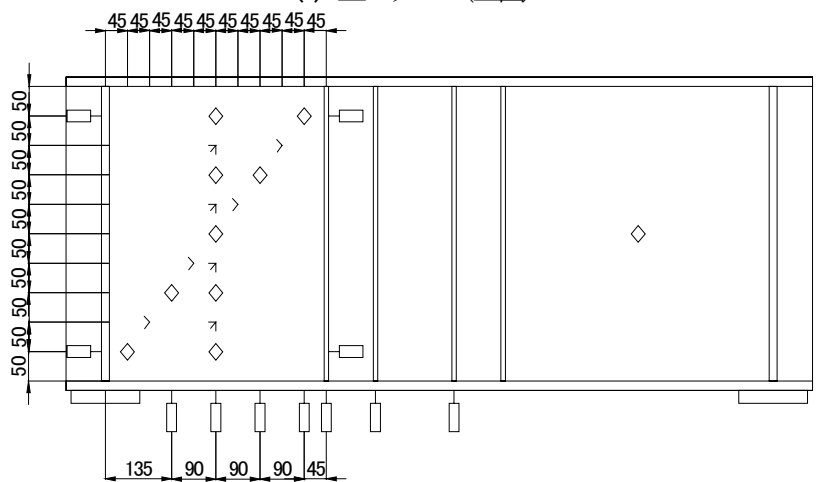

(b) 側面図

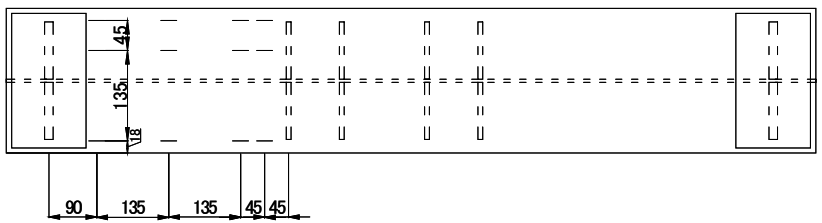

(c) 下フランジ

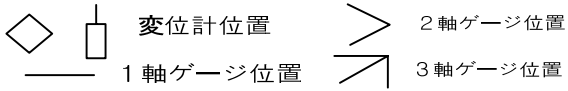

図-4 ひずみと変位の測定位置（、法単位: mm) 
表-3 材料試験結果（SS400）

\begin{tabular}{|c|c|c|c|c|c|}
\hline 材料定数 & $\begin{array}{c}\text { 降伏点 } \sigma_{y} \\
\left(\mathrm{~N} / \mathrm{mm}^{2}\right)\end{array}$ & $\begin{array}{c}\text { 引張強度 } \sigma_{u} \\
\left(\mathrm{~N} / \mathrm{mm}^{2}\right)\end{array}$ & $\begin{array}{c}\text { ヤング率 } E \\
\left(\mathrm{~N} / \mathrm{mm}^{2}\right)\end{array}$ & $\begin{array}{c}\text { ポアソン } \\
v\end{array}$ & 降伏比 \\
\hline $\begin{array}{c}\text { 腹板パネル } \\
\text { (板厚4.5mm) }\end{array}$ & 289 & 438 & $2.02 \times 10^{5}$ & 0.31 & 0.66 \\
\hline $\begin{array}{c}\text { 上下フラジ } \\
\text { (板厚 } 16 \mathrm{~mm} \text { ) }\end{array}$ & 299 & 451 & $2.01 \times 10^{5}$ & 0.24 & 0.66 \\
\hline $\begin{array}{c}\text { 垂直補剛材 } \\
\text { (板厚 } 16 \mathrm{~mm}, 9 \mathrm{~mm} \text { ) }\end{array}$ & 299 & 451 & $2.01 \times 10^{5}$ & 0.24 & 0.66 \\
\hline
\end{tabular}

表-4 初期たわみの最大值と最小值（単位 : $\mathrm{mm}$ )

\begin{tabular}{|c|c|c|c|}
\hline \multirow{2}{*}{ 初期たわ試体 } & Type-I & Type-II & Type-III \\
\cline { 2 - 4 } & Panel A & Panel A & Panel A \\
\hline 最大值 & 1.82 & 0.38 & 0.67 \\
\hline 最小值 & -1.09 & -0.62 & -1.98 \\
\hline
\end{tabular}

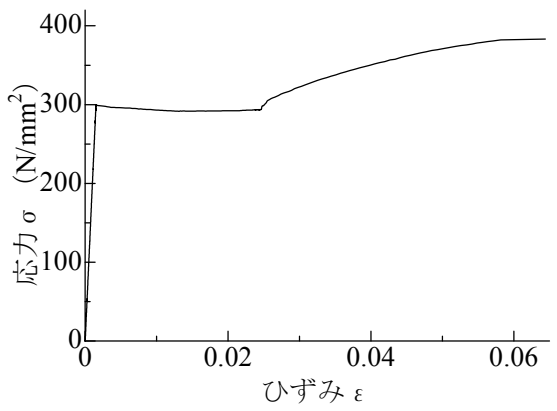

(a) 腹板 (板厚 $4.5 \mathrm{~mm}$ )

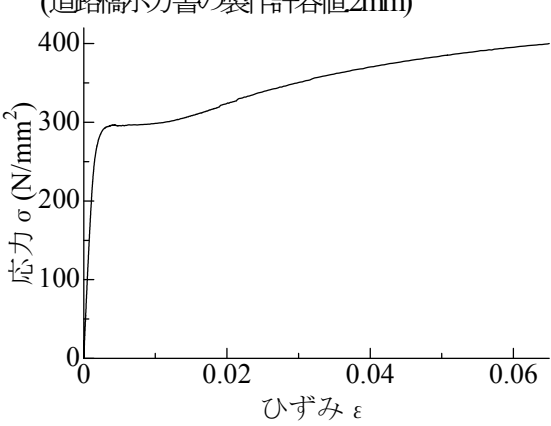

(b) 上下フランジ(板厚 $16 \mathrm{~mm}$ )

図-5 実験供試体に用いた鋼板の応力ーひずみ関係(実測值)

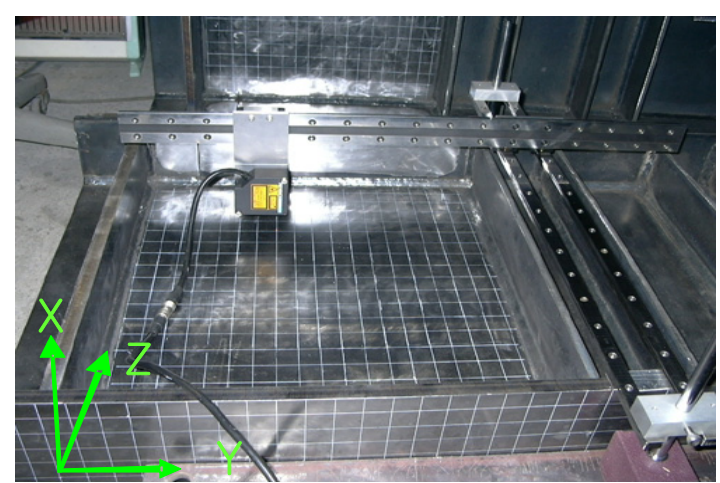

（a）計測状況

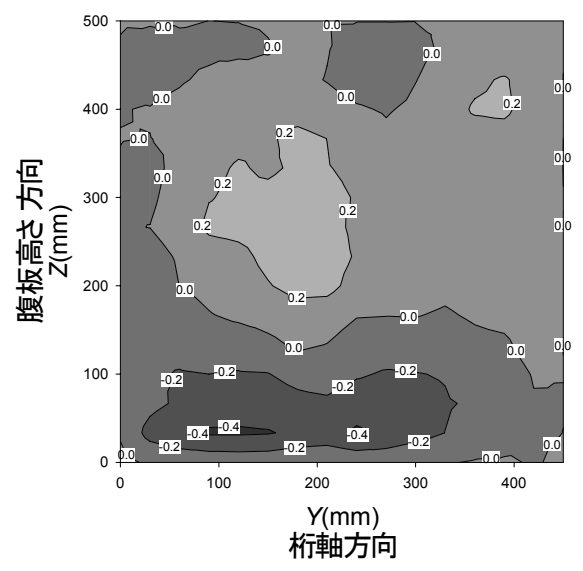

(c) Type-II

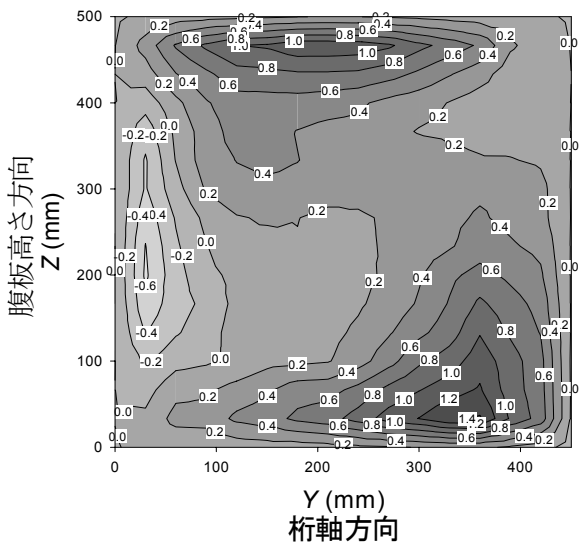

(b) Type-I

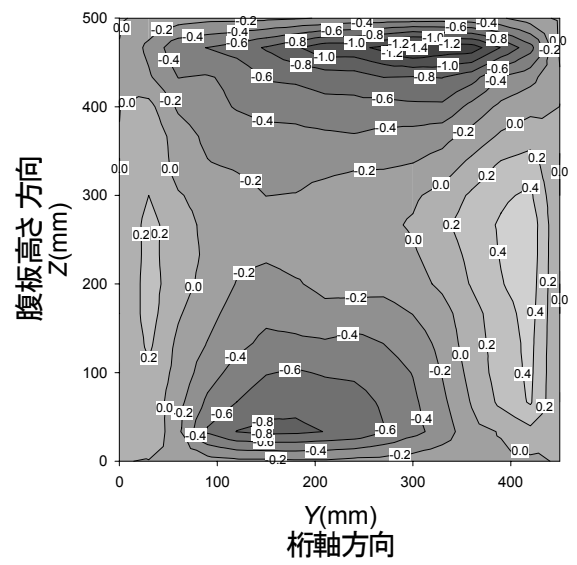

(d) Type-III

図-6 着目腹板パネル初期たわみの計測結果（単位: $\mathrm{mm}$ ) 


\section{b）初期たわみの計測}

初期たわみは, 腹板パネル上にセットしたフレーム上を 縦横に移動可能なレーザー変位計を用いて計測した。測 定点は，腹板パネルの部材軸方向 $(Y$ 方向 $)$ と高さ方向 $(Z$ 方向）にそれぞれ 20 分割し，その交点とした. 腹板パネ ルの初期たわみ方向を $X$ 軸としている．レーザー変位計 の分解能は $2 \mu \mathrm{m}\left(2 \times 10^{-3} \mathrm{~mm}\right)$ であり, 基淮距離 $40 \mathrm{~mm}$ から $\pm 5 \mathrm{~mm}$ まで測定可能である. 計測の状況と測定した初期 たわみの結果を図-6に示寸．下フランジと腹板の交線お よび支点上垂直補岡忉と腹板の交線を初期たわみ 0 とし た. また，初期たわみの最大值と最小值を表-4にまとめ る.

この表より腹板の初期たわみの絶対最大值は，実験供 試体 Type-I，Type-II，およびType-III に対して，それぞれ $h / 275, h / 807, h / 253$ ( $h:$ 腹板高さ) となり, 道路橋示方 書のに定められた製作基準の許容值 $h / 250$ を満足している ことがわかる．また，絶対最大值は，腹板とフランジの 溶接線近傍(溶接線から約 $20 \mathrm{~mm}$ ) で発生している.

\section{3. 実験結果と考察}

\section{（1）作用せん断力と腹板パネル変位との関係}

作用せん断力 $V$ と腹板パネル中央の面外変位 $\delta_{w}$ との関係を, $V-\delta_{w}{ }^{2}$ 曲線としてプッロットしたものを図一7に示寸.いずれの実 験共試体も腹板にせん断座屈力溌生した後, 斜張力場を形成し, 上下フランジに塑性ヒンジ的な現象力汧成され終局状態に至っ た

柱の座屈荷重の判定に用いられる $P-\delta^{2}$ 法7) 準用して,

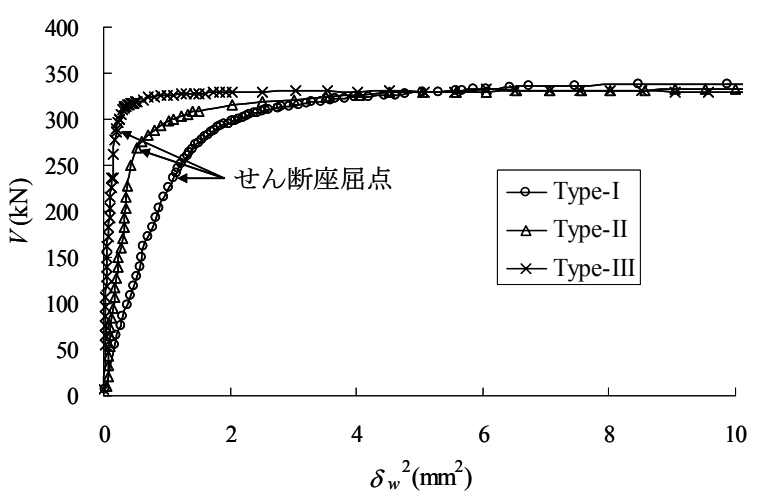

図-7 $\quad V-\delta_{w}{ }^{2}$ 曲線
腹板の座屈せん断力は, $V-\delta_{w}{ }^{2}$ 曲線の勾配が初期勾配から 大きく変化する荷重レベルとして定義し，図-8 に示す $V-\delta_{w}{ }^{2}$ 曲線の微係数が大きく低下寸る点として求めた。 ま

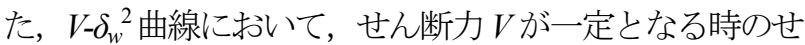
ん断力を終局せん断力とした，座屈せん断力と終局せん 断力を表-5にまとめる. 表-5および図-7よりわかるよう に, 腹板パネルに模擬き裂を有する供試体 Type-III が最も 座屈せん断力が大きい結果を得た. これは, 後述するが, 腹板内にき裂が存在することにより，楕円状のせん断座 屈波形が上フランジ側に上昇し幅も狭くなり，実質的な 腹板パネルの縦横比(アスペクト比)が小さくなるためで ある。一方，模擬き裂がある場合の終局せん断力につい ては，き裂がない場合に比べて若干低下寸る傾向がある が大きな変化は見られなかった．このように，本研究で 設定した模擬き裂に関しては，その有無による終局せん 断力の低下は少なく, 疲労き裂が下フランジを貫通し腹 板にまで進展した時点においても十分な残存せん断耐荷 力があると判断される.

\section{（2）終局状態}

載荷実験終了後の腹板の座屈变形の状況を写真-2 に示 す．模擬き裂を有さない健全な供試体 Type-I では，腹板 の局部座屈変形が，ほぼ腹板パネルの対角線方向を通っ ているのに対し，模擬き裂を有する供試体 Type-II および Type-III ではき裂の影響により，その発生位置が上方に移 動している．ただし，下フランジのみに模擬き裂を想定 した供試体 Type-II では，この上方への移動は Type-III に 比べて小さく，座屈せん断力の変化も少ない.
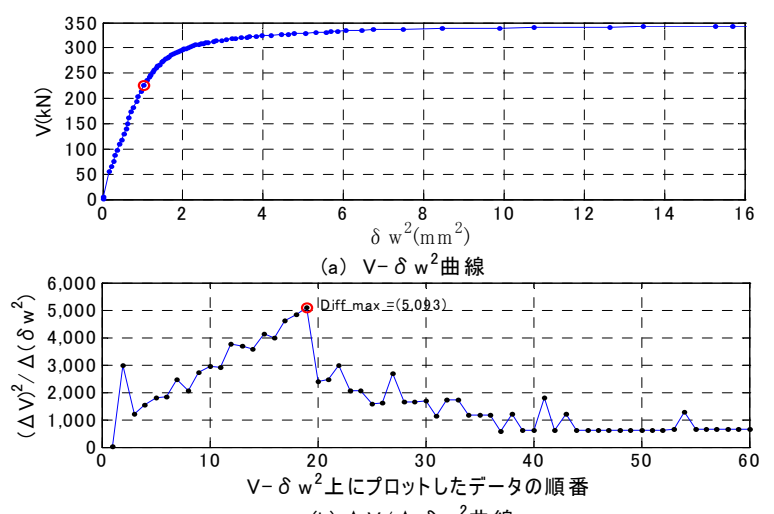

(b) $\Delta V / \Delta \delta w^{2}$ 曲線

図-8 座屈せん断力の定義

表-5 座屈せん断力と終局せん断力の実験值

\begin{tabular}{|c|c|c|}
\hline 供試体 & $\begin{array}{c}\text { 座屈せん断力 } \\
V_{c r}{ }^{e}(\mathrm{kN})\end{array}$ & $\begin{array}{c}\text { 終局せん断力 } \\
V_{u}{ }^{e}(\mathrm{kN})\end{array}$ \\
\hline Type-I & 247.5 & 342.2 \\
\hline Type-II & 260.8 & 335.5 \\
\hline Type-III & 271.0 & 332.2 \\
\hline
\end{tabular}




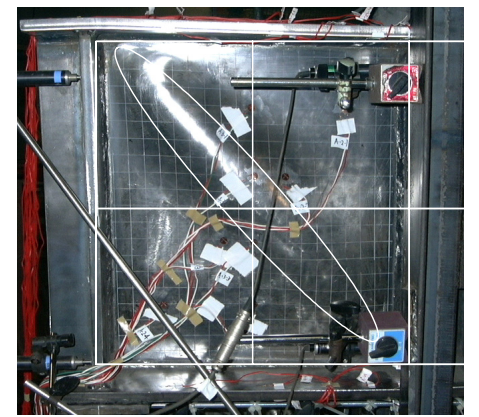

(a) Type-I

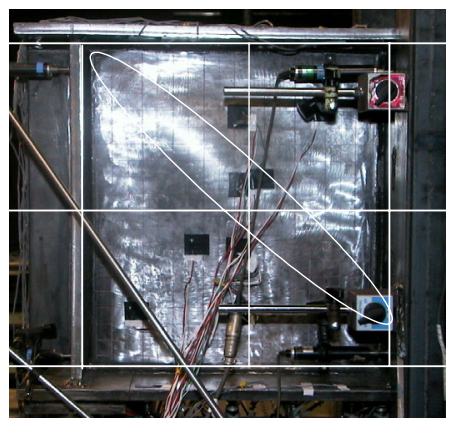

(b) Type-II

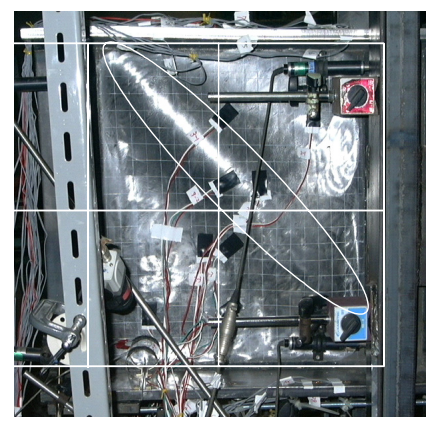

(c) Type-III

写真-2 載荷実験終了後の腹板パネルの変形状況

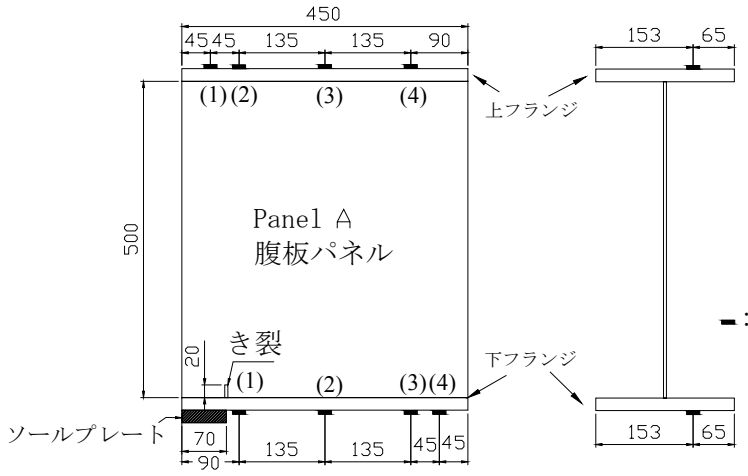

(a) ひずみゲージの貼り付け位置

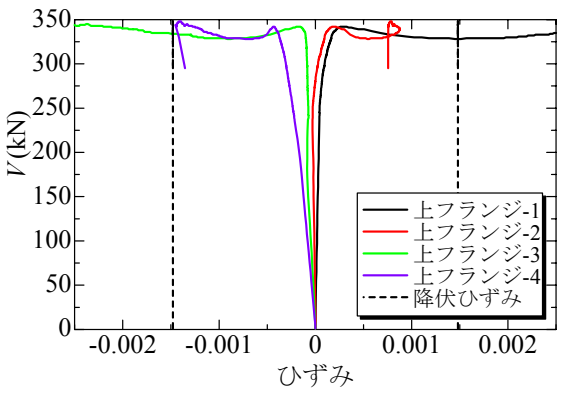

i）上フランジ

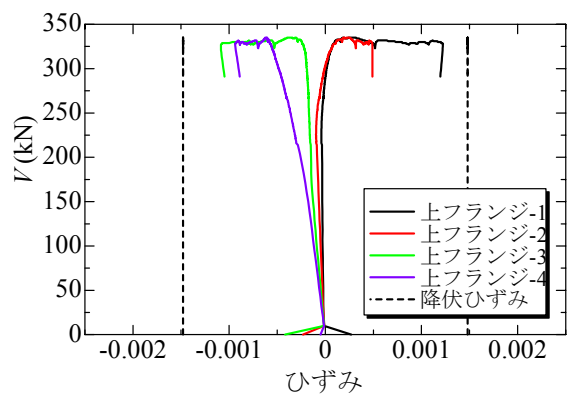

i）上フランジ

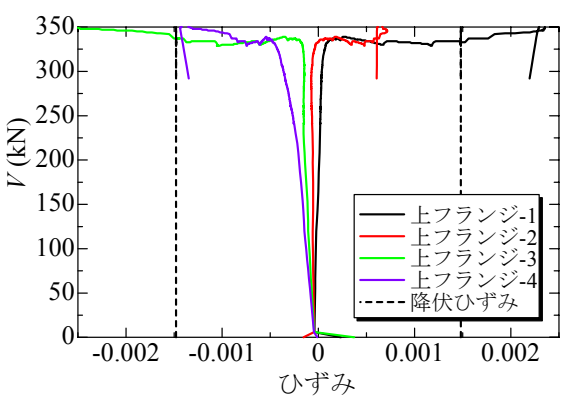

i）上フランジ

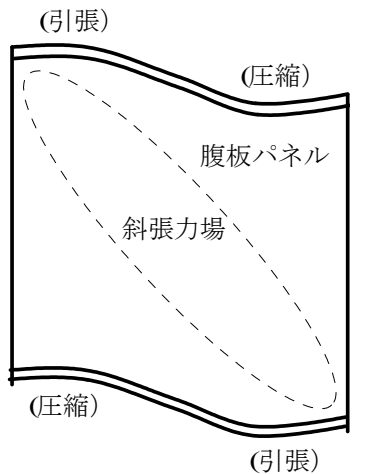

(b) 推定塑鏰壊モード

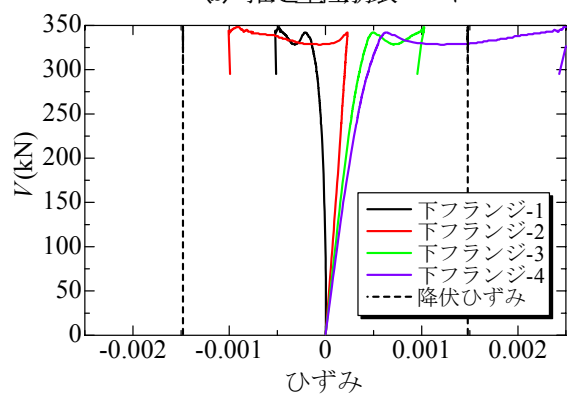

ii)下フランジ

(c) Type-I

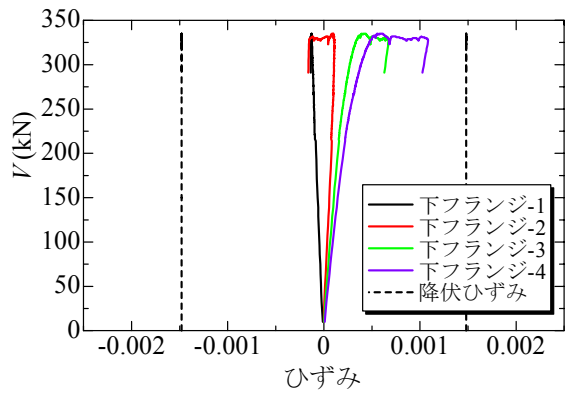

ii)下フランジ

(d) Type-II

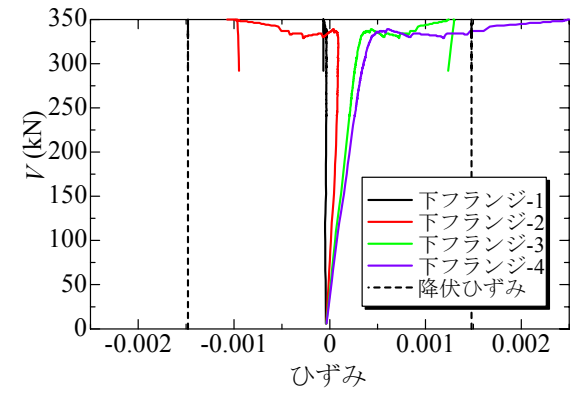

ii)下フランジ

(e) Type-III

図-9 各荷重段階における上フランジのひずみ 
図-9 は，着目腹板パネルの周辺のラーメン構造の崩壊 メカニズムを調べるために上下フランジに貼ったひずみ ケージのひずタ值を作用せん断力との関係でプロットし たものである. 図-9(a) はひずみゲージの貼り付け位置を 示している. 図-9 (c) と (e)に示す Type-I および Type-III 供試体では上フランジの(1)および(2)で引張ひずみが発生 し，降伏ひずみに達しているものがあること，(3)および (4)では圧縮ひずみが発生していること. 下フランジの(3) および(4)においては上フランジとは逆対象的に引張応力 が発生して，降伏ひずみを超えている．このことから塑 性上下フランジで桁軸方向に全面的に降伏寸る崩壊モ一 ド(図-9 (b) 参照)的な現象が発生していると考えられる. 図-9(d)に示す Type-II 供試体については, Type-I および Type-III 供試体と同様の傾向は認められる. しかし，降伏 ひずみには達してはいないがそれに近いひずみが発生し ている. したがって，Type-II 供試体についても Type-I お よび Type-III 供試体と同様な状態に近いと考えられる.

実験終了後，き裂を有する Type-II と Type-III のき裂周 辺の状況を目視により観察した，その結果，き裂の進展 を確認することはできなかった．また，残留開口部の相 対変位は，き裂先端での塑性化の影響によりせん断方向 (鉛直方向)に約 $0.5 \mathrm{~mm}$ であった。

\section{（3）腹板のひずみ分布}

図-10 には，腹板パネルの対角線上 $\mathrm{C}$ 点における $\mathrm{BB}$ 方向およびその直角方向の表面および裏面のひずみの変 化と作用せん断力との関係を示寸．図中には，前節で示

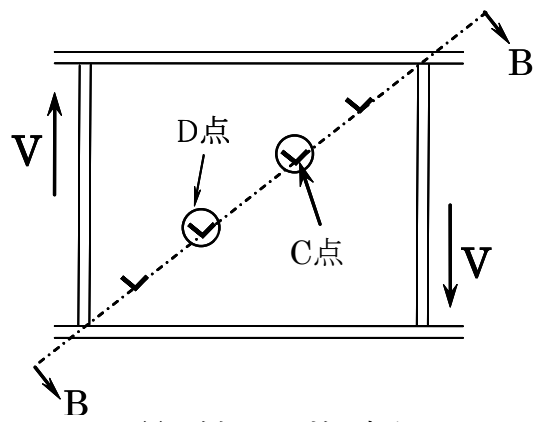

(a) 腹板のひずみ方向

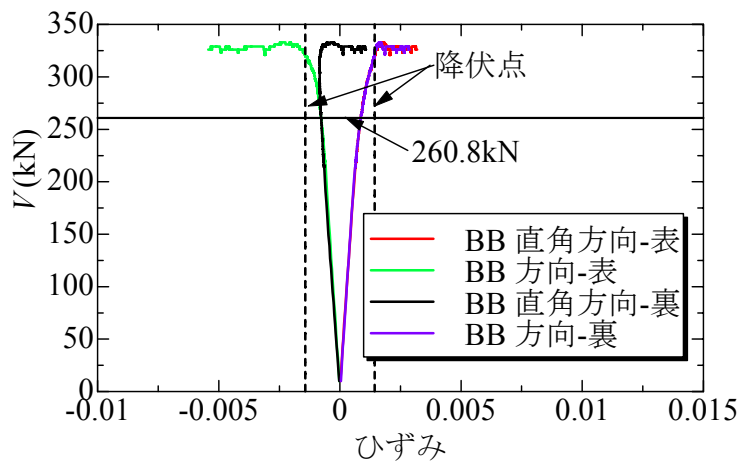

(c) Type-II
した定義に従って求めた座屈せん断力を参考に示してい る. 図-10より, 腹板パネルが座屈し始め, 腹板パネル裏 表のひずみ差が大きくなり，腹板パネルが座屈変形する せん断力，すなわち実験ひずみから座屈せん断力を求め ることができる． C 点および D 点においてひずみ差から 求めた座屈せん断力を表-6 に示す. 座屈せん断力は $\mathrm{C}$ 点 と D 点の荷重レベルの内の小さい方としている. 表より, $V-\delta_{w}{ }^{2}$ 曲線から求めた座屈せん断力よりもこれらの值が大 きくなっていることがわかる．また，Type-II 供試体およ びType-III 供試体でその大小関係が逆転している.これは, ひずみ差から座屈せん断力を求める場合，あくまでひず みゲージを貼った位置での局部曲げ変形を計測している ことから，計測位置と座屈変形が発生する場所に差異が あったためと考えられる．特に，本実験ではひずタゲー ジの位置が腹板の中央から離れていることから，図-10 から求めた座屈せん断力が， $V-\delta_{w}{ }^{2}$ 曲線から求めた值より も大きくなっていると考えられる.

さらに，腹板パネルに貼付けた裏表の 3 軸ひずみゲー ジの平均值から，主ひずみの大きさとその方向を求めた.

表-6 C 点およびD 点のひずみから決定される座屈せん断力

\begin{tabular}{|c|c|c|}
\hline \multirow{2}{*}{} & \multicolumn{2}{|c|}{ 座屈せん断力 $(\mathrm{kN})$} \\
\cline { 2 - 3 } & C点 & D点 \\
\hline Type-I & 340 & 280 \\
\hline Type-II & 300 & 320 \\
\hline Type-III & 275 & 340 \\
\hline
\end{tabular}

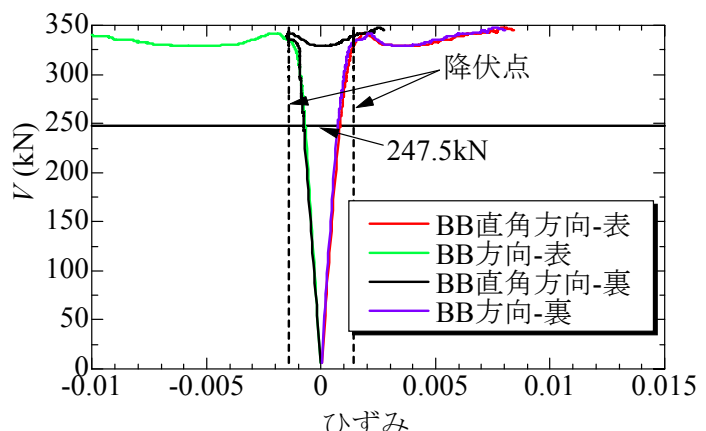

(b) Type-I

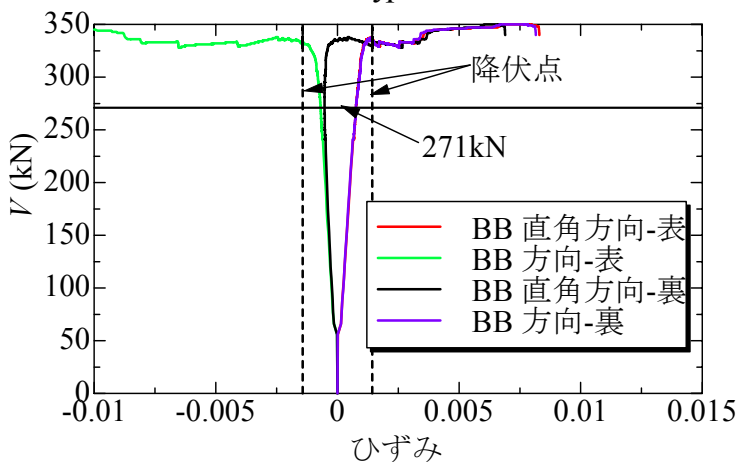

(d) Type-III

図-10 各荷重段階における腹板の対角方向ひず夕 $\varepsilon_{d}$ の分布 
それぞれの実験供試体で，弾性域と考えられる比較的 低い荷重段階（初期段階）と，終局荷重付近の荷重（終 局せん断力）段階におけるこれらの結果を図-11 に示す.

すべての実験供試体において，初期段階である弾性範 囲内では，主ひずみの大きさとその方向は腹板の全面で 均一であり, その方向はほぼ $45^{\circ}$ である. これより, 着目 している腹板パネルは純せん断に近い状態であると判断

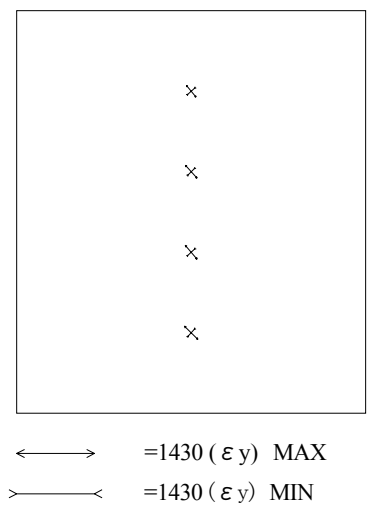

i)初期股皆 $V=108(\mathrm{kN})$

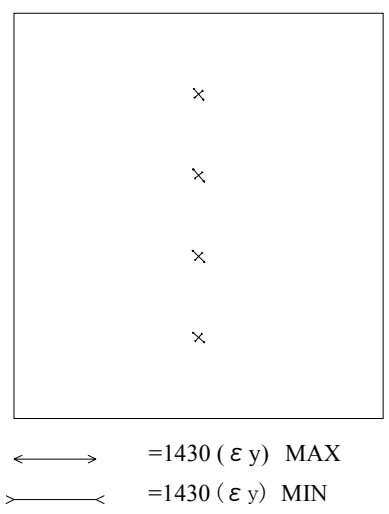

i)初期段皆 $V=107(\mathrm{kN})$

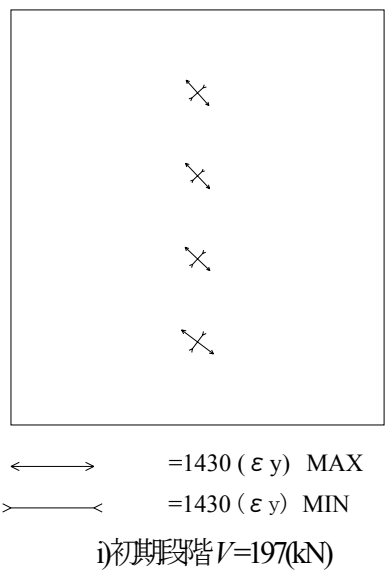

(c) Type-III
できる.

また，終局荷重段階において，き裂のない Type-I 供試 体では腹板パネルの中央部から上部に大きな主ひずみが 現れているが，き裂のある Type-II および Type-III 供試体 ではパネル上部に大きな主ひずみが現れ，斜張力場がき 裂の存在により上方に移動したことが読みとれる.

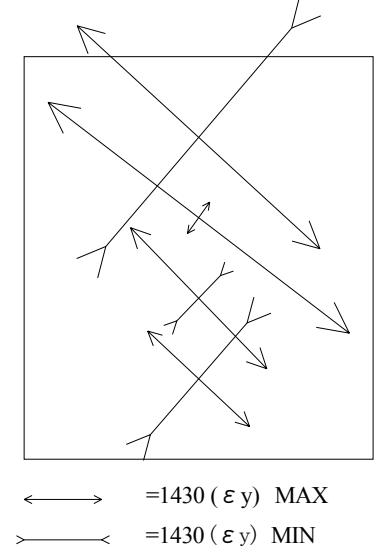

ii)終局荷重（終局せん断力）付近 $V=329(\mathrm{kN})$

(a) Type-I

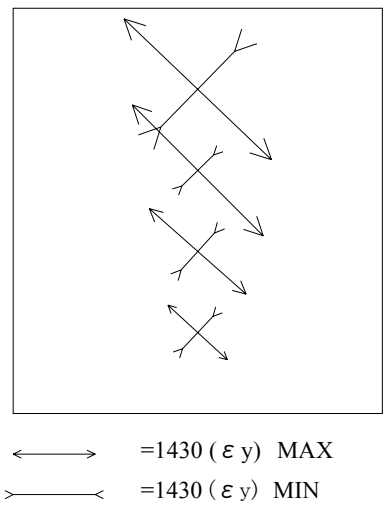

ii)終局荷重(終局せん断力)付近 $V=329(\mathrm{kN})$

(b) Type-II

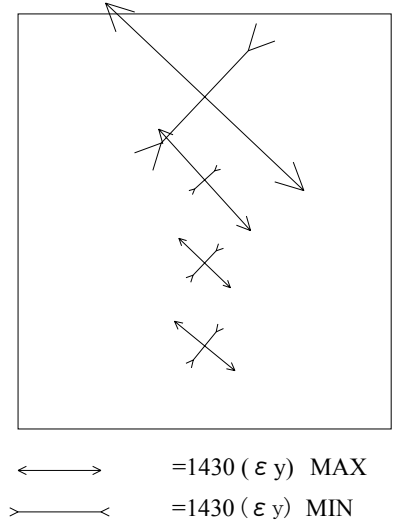

ii)終局荷重(終局せん断力)付近 $V=330(\mathrm{kN})$

図-11 主ひずみ分布 


\section{(4) 座屈せん断力と終局せん断力の評価}

図-12 および表-7 には, 式(2a)より求められる腹板パネ ル(Panel A) の座屈せん断応力度の理論值と実験結果との 比較, 座屈せん断力の理論值と実験結果との比較を示寸. 座屈せん断力 $V_{c r}$ の理論值は, 式(2b)により求めた ${ }^{5}$. 本 実験における対象パネルの幅厚比パラメータ $R_{\tau w}$ は 1.1 で あることから，下にある第2式を用いている.

$$
\left.\begin{array}{rl}
\tau_{c r} / \tau_{y}=1 & : R_{\tau w} \leq 0.6 \\
=1-0.614\left(R_{\tau w}-0.6\right) & : 0.6<R_{\tau w} \leq \sqrt{2} \\
= & 1 / R_{\tau w}^{2} \quad: \sqrt{2}<R_{\tau w}
\end{array}\right\}
$$

ここで， $A_{w}$ は腹板パネルの断面積である.

図-12 の曲線は参考文献 5)の終局せん断念力曲線である式(2a) を本実験結果と比較して示したものである.

Baslerによる終局せん断力 $V_{u}$ は，式(2c)で与えられる. ここで は, これを終局せん断力の理侖值とし, 表-7 に座屈せん断力と 同様に実験結果と比較している.

$$
V_{u}=V_{p}\left\{\frac{\tau_{c r}}{\tau_{y}}+\frac{1-\left(\tau_{c r} / \tau_{y}\right)}{1.15 \sqrt{1-\alpha^{2}}}\right\}
$$

ここに, $V_{p}$ は腹板パネルの全断面降伏せん断力であり， $\alpha$

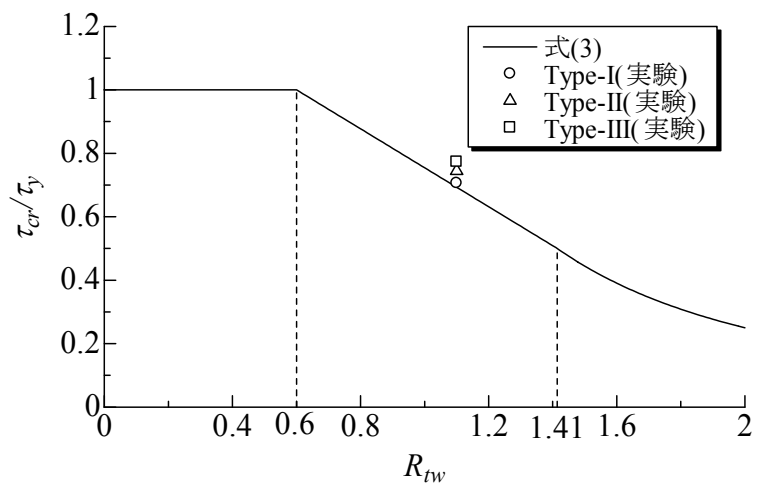

図-12 単一パネルの座屈せん断応力度曲線と 実験座屈せん断応力度
はアスペクト比である.

表-7 より, 座屈せん断力はき裂の存在により大きくな っていることがわかる。これは，以下で述べる固有值解 析による座屈モードからは必ずしも明確でないが，以下 の理由によるものと考えられる. 寸なわち, き裂の位置 で座屈波形の連続性がなくなり，実質的に下フランジ側 の腹板パネル長が短くなるためと仮定することができる.

この仮定に従って，表-5に示したき裂のある場合の座 屈せん断力の理論值は, き裂の存在によりアスペクト比 が変化すると考えこれを考慮して求めたものである．な お，き裂がない上フランジ側の腹板パネル長は変化しな いが，簡単のため，上フランジ側の腹板パネル長も下フ ランジ側と同じように短くなるものと仮定した．図-13 には，表-5 の理論值 $V_{c r}$ および $V_{u}$ の計算に用いた実質的 な腹板パネルのアスペクト比の取り方の模式図を示寸.

図-12 と表-7 の結果から，き裂の存在が腹板パネルの座 屈せん断応力度に及ぼす影響は，アスペクト比を小さく することで考慮することができることがわかる.

終局せん断力の実験值はき裂の増加によりやや低下寸 る傾向にある. 式(2c)では, フランジの貢献を無視してお り，き裂のない Type-I 供試体の理論值と実験值との間で も差異が認められる．また，き裂のある Type-II およびIII 供試体についても式(2c)による理論值は実験值と異なっ ており，き裂の影響も正しく考慮できていないことがわ かる.

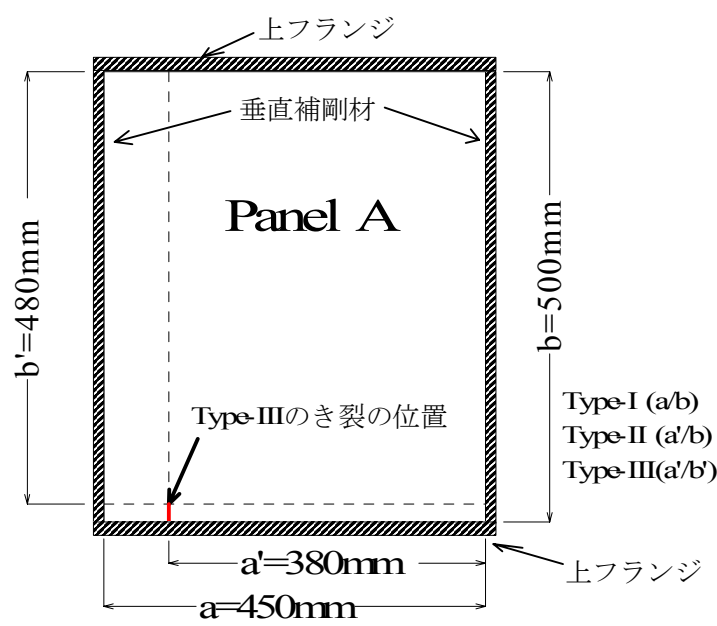

\begin{tabular}{|c|c|c|c|c|c|c|c|c|}
\hline \multirow{2}{*}{ 供試体 } & \multicolumn{2}{|c|}{$\begin{array}{c}\text { 座屈せん断力 } \\
V_{c r}(\mathrm{kN}) \\
\end{array}$} & \multicolumn{2}{|c|}{$\begin{array}{c}\text { 終局せん断力 } \\
V_{u}(\mathrm{kN}) \\
\end{array}$} & \multirow{2}{*}{$V_{c r}{ }^{\prime} / V_{c r}$} & \multirow{2}{*}{$V_{u}{ }^{\prime} / V_{u}$} & \multirow{2}{*}{$\begin{array}{c}\text { 理論值 } V_{c r}, V_{u} \text { に } \\
\text { 用いた } \\
\text { アスペクト比 } \alpha\end{array}$} & \multirow{2}{*}{$\begin{array}{c}\text { 理論值 } V_{c r}, V_{u} \text { に } \\
\text { 用いた } \\
\text { 幅厚比パラメータ } \\
R_{\tau w} \\
\end{array}$} \\
\hline & $\begin{array}{c}\text { 実験值 } \\
V_{c r}{ }^{\prime}\end{array}$ & $\begin{array}{c}\text { 理論值 } \\
V_{c r} \\
\end{array}$ & $\begin{array}{c}\text { 実験值 } \\
V_{u}{ }^{\prime}\end{array}$ & $\begin{array}{c}\text { 理論值 } \\
V_{u} \\
\end{array}$ & & & & \\
\hline Type-I & 247.5 & 245.8 & 342.2 & 312.2 & 1.01 & 1.10 & $0.9(a / b)$ & 1.23 \\
\hline Type-II & 260.8 & 270.9 & 335.5 & 380.6 & 0.96 & 0.88 & $0.76\left(a^{\prime} / b\right)$ & 0.98 \\
\hline Type-III & 271.0 & 262.6 & 332.2 & 371.0 & 1.03 & 0.90 & $0.79\left(a^{\prime} / b^{\prime}\right)$ & 0.97 \\
\hline
\end{tabular}

図-13 理論值 $V_{c r} V_{u}$ の計算に用いたアスペクト比

表-7 座屈せん断力と終局せん断力 


\section{4. き裂長をパラメータとした弾塑性有限変位解析}

\section{（1）解析モデルおよび解析条件}

解析には板構造の弾塑性有限変位解析で実績のある FEM 解析コードUSSP ${ }^{8}$ を用いた，解析モデルは，実験供 試体の実測寸法に基づいて作成した.

腹板の初期たわみ $\left(W_{o, w}\right)$ には 2. (3) で示した実測值を再 現し用いている.

フランジプレートの初期たわみについては, 図-14 に示 すように垂直補岡材取付け位置を節とする局部的な初期 たわみ波形と桁全体に渡る初期たわみ波形とを重ね合わ せた初期たわみを設定した。設定した波形は，それぞれ 以下の式(3a)と式(3b)で表される． $Z_{0}$ はフランジの局部的 な初期たわみ波形， $Z_{a}$ は供試体全体にわたる初期たわみ 波形を表している. なお，初期たわみの最大值は，道路 橋示方書9)で規定されている製作許容值とした.

$$
\begin{aligned}
Z_{0} & =w_{0 \max , f} \sin \left(\frac{\pi Y}{a}\right) \frac{2 X}{b} \\
Z_{a} & =w_{a \max , f} \sin \left(\frac{\pi Y}{L}\right) \\
w_{0 \max , f} & =b / 2 \times 100 \text { および } w_{a \max , f}=L / 1000
\end{aligned}
$$

ここで， $a$ は垂直補岡彬間隔， $L$ は供試体長， $b$ はフラン ジ幅である。

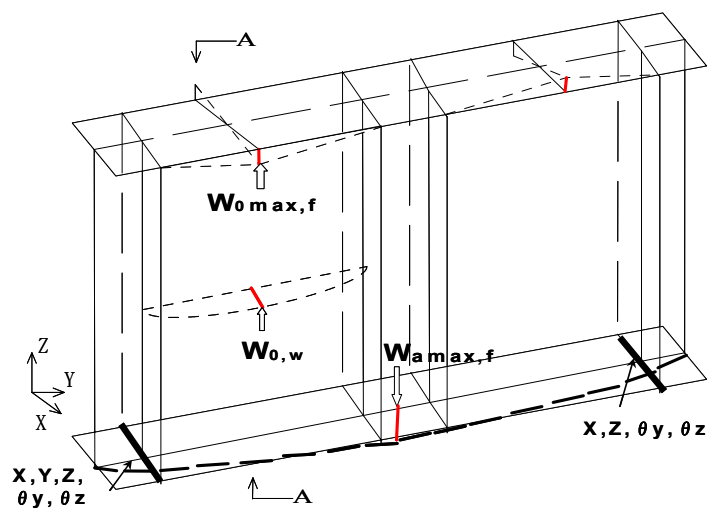

(a) 側面図

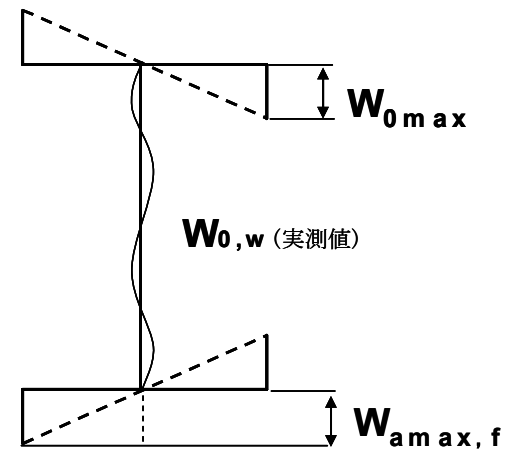

(b) 断面図(断面 $\mathrm{AA}^{\prime}$ )

図-14 解㸫に用いた初期たわ子波形
残留応力分布は，文献 5)を参考にして，図-15 に示す 分布形とした.

下フランジと腹板に導入したき裂は，曲げモーメント も載荷されることから，開口部が閉じる方向への変位は 生じないことを確認し，図-16 に示すように，節点間の 圧縮は生じないとして初期座標を共有する独立節点とし てモデル化している.

本解析で用いた鋼材の機械的性質および応力ーひずみ 関係は，材料試験より得られた結果を参考にして決定し ている，その応力ーひずみ関係の一例を図-17 に示すが, 降伏棚とひずみ硬化領域を有するトリリニア型に理想化 した.

解析モデルの境界条件は, 回転支点およびローラー支点 となるように下フランジの支点上の節点に, それぞれ適 切に与えた. 載荷は, 載荷点である上フランジの中央部分 の変位を強制漸増する変位制御で導入した.

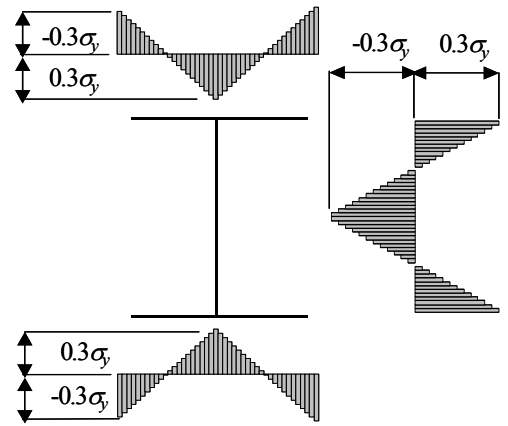

図-15 解析で仮定した残留応力分布

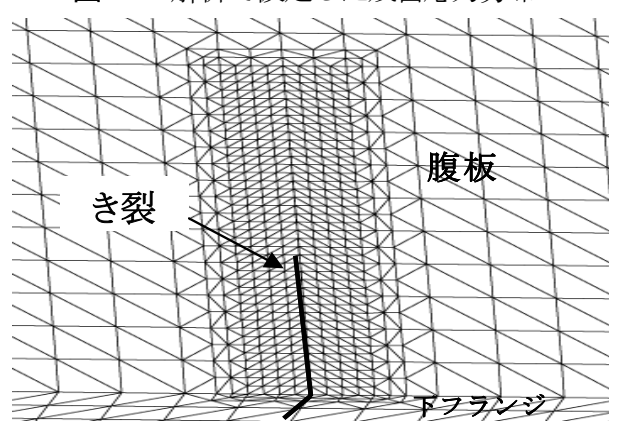

図-16 き裂付近の要素分割の状況 (供試体 Type-III)

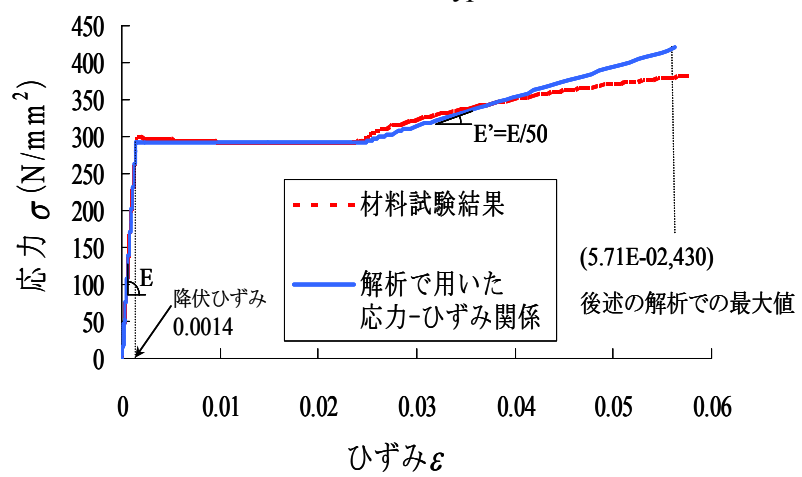

図-17 腹板材料の応力ーひずみ関係 


\section{（2） 解析モデルの検証}

\section{a）腹板の面外変位}

まず，弾性固有值解析により得られた座屈モードを図 -18 に示寸.

Type-I と Type-II との比較では, き裂のない Type-I に比 ベてフランジにき裂を有する Type-II $の$ 座屈モードが上方 に移動し, 楕円形座屈波形の幅が狭くなる傾向が見られ る. Type-III については，わずかではあるが，座屈モード がType-II より上方に移動し座屈波形の幅が小さくて長く なっていることがわかる.

次に，弾塑性有限変位解析より得られた作用せん断力 と腹板パネル中央の面外変位との関係 $\left(V-\delta_{w}{ }^{2}\right.$ 曲線 $)$ を図 -19 に，また，この図より求めた座屈せん断力および終 局せん断力の解析結果と実験結果との比較を表-7 亿示寸.

さらに，腹板の初期たわみ波形の而荷力に与える影響 を明らかにするため, 弾性固有值解析から得られた一次 座屈モードを腹板の初期たわみ波形として導入する，弾 塑性有限変位解析も行った。 設定した初期たわみの最大 值および残留応力は既に述べたとおりである。これらの 得られた座屈せん断力之終局せん断力についても表-7に その結果を示す。
座屈せん断力は, 3.1 で示した載荷実験における座屈 せん断力と同様に， $V-\delta_{w}{ }^{2}$ 曲線の勾配が初期勾配から大き く変化する点として定義し求めた. 終局せん断力は作用 せん断力の最大值として求めた.

これらの実験結果と解析結果との比較から，両者は良 好に一致していることがわかる.

ただし，いずれのケースも作用せん断力と腹板パネル 中央の面外変位の関係において，初期の曲線の傾きが実 験結果と解析結果とで異なっている。これは，解析にお いて導入した腹板パネル，特にフランジプレートの初期 たわみが完全に実際の初期たわみと一致しないことが原 因として考えられる.

表-8 より，座屈せん断力および終局せん断力の実験結 果と解析結果の比は Type-I ではともに 0.98 を, Type-II で は座屈せん断力は 1.01, 終局せん断力は 0.97 を, Type-III では, それぞれ 1.08 と 1.02 を示している. また, 弾性固 有值解析による座屈モードから求めた初期たわみと実測 の初期たわみを用いた解析では，Type-III を除き，実測の 初期たわみを用いた解析の方が実験值に近い值が得られ ている.

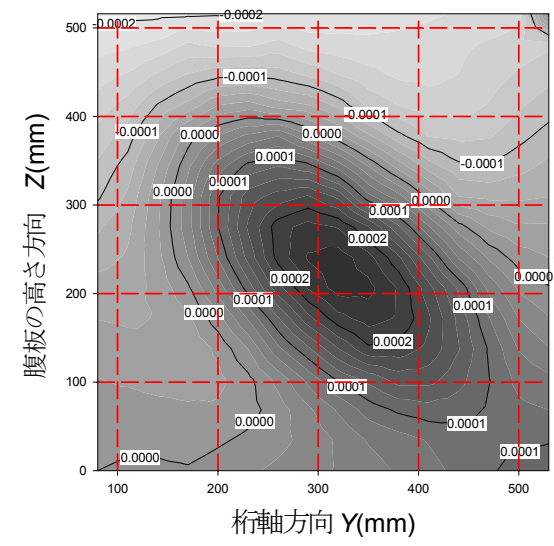

(a) Type-I

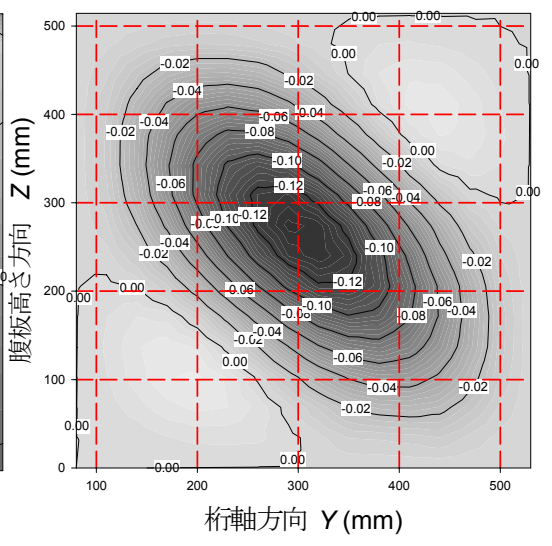

(b) Type-II

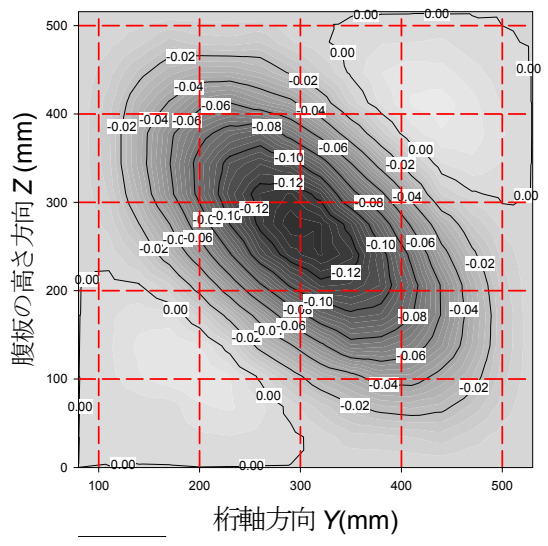

(c) Type-III

図-18 固有值解析で得られた座屈モード

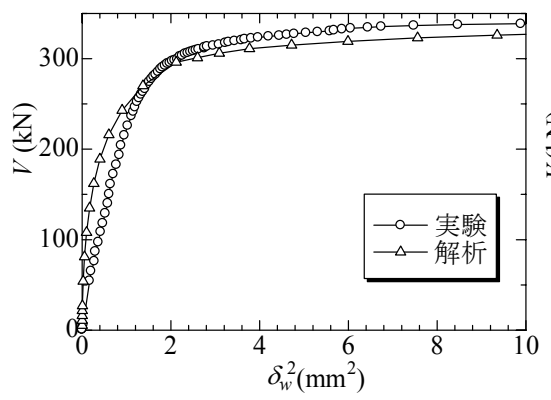

(a) Type-I

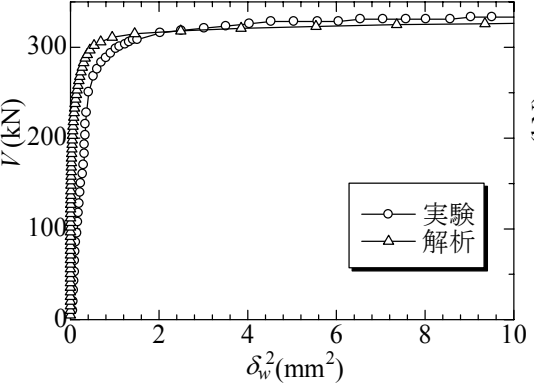

(b) Type-II

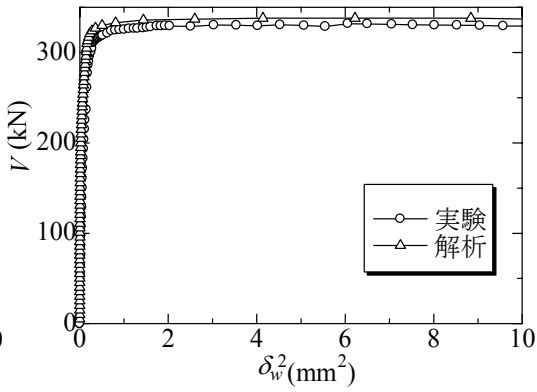

(c) Type-III

図-19 作用せん断力と面外変位との関係 $\left(V-\delta_{w}{ }^{2}\right)$ 
表-8 実験值と解析值との比較

\begin{tabular}{|c|c|c|c|c|c|c|c|c|c|c|}
\hline \multirow{2}{*}{ 供試体 } & \multicolumn{3}{|c|}{$\begin{array}{c}\text { 座屈せん断力 } \\
V_{c r}(\mathrm{kN})\end{array}$} & \multicolumn{3}{|c|}{$\begin{array}{c}\text { 終局せん断力 } \\
V_{u}(\mathrm{kN})\end{array}$} & \multirow{2}{*}{$V_{c r}(a) / V_{c r}(e)$} & \multirow{2}{*}{$V_{u}(a) / V_{u}(e)$} & \multirow{2}{*}{$V_{c r}\left(a^{\prime}\right) / V_{c r}(e)$} & \multirow{2}{*}{$V_{u}\left(a^{\prime}\right) / V_{u}(e)$} \\
\hline & $\begin{array}{l}\text { 実験值 } \\
V_{c r}(e)\end{array}$ & $\begin{array}{l}\text { 解析値 } \\
V_{c r}(a)\end{array}$ & \begin{tabular}{|c|} 
固有値解析 \\
$V_{c r}\left(a^{\prime}\right)$
\end{tabular} & $\begin{array}{l}\text { 実験値 } \\
V_{u}(e)\end{array}$ & $\begin{array}{c}\text { 解析值 } \\
V_{u}(a)\end{array}$ & $\begin{array}{c}\text { 固有值解析 } \\
V_{u}\left(a^{\prime}\right)\end{array}$ & & & & \\
\hline Type-I & 247.5 & 242.4 & 258.4 & 342.2 & 336.7 & 324.5 & 0.98 & 0.98 & 1.04 & 0.95 \\
\hline Type-II & 260.8 & 263.3 & 270.5 & 335.5 & 326.7 & 352.8 & 1.01 & 0.97 & 1.04 & 1.05 \\
\hline Type-III & 271.0 & 291.9 & 277.7 & 332.2 & 338.3 & 347.9 & 1.08 & 1.02 & 1.02 & 1.05 \\
\hline
\end{tabular}

固有值解析 : 固有值解析で得られた 1 次モードを初期たわみ変形とした解析
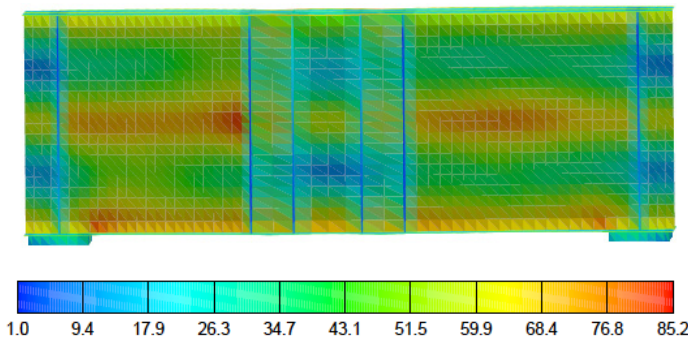

i) $V=37.6 \mathrm{kN}$ 時 $\left(V / V_{u}=0.112\right)$
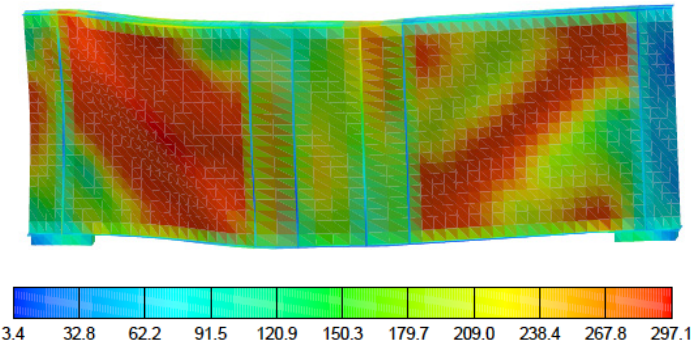

ii)終局状態 $\left(V_{u}=336.7 \mathrm{kN}, \sigma_{y}=289 \mathrm{~N} / \mathrm{mm}^{2}\right)$

（a）Type-I(き裂なし)
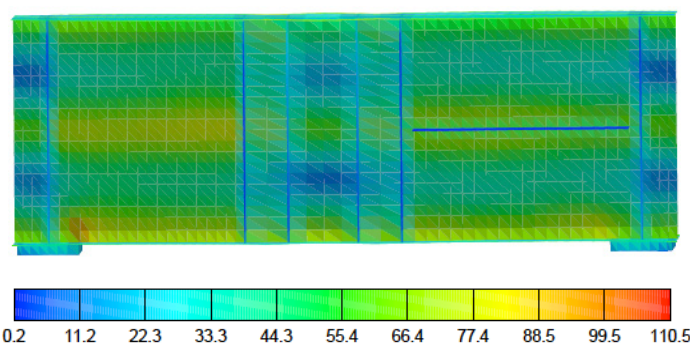

i) $V=37.6 \mathrm{kN}$ 時 $\left(V / V_{u}=0.115\right)$
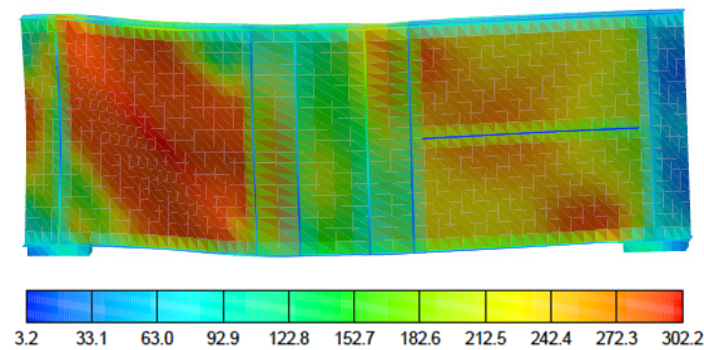

ii)終局状態 $\left(V_{u}=326.7 \mathrm{kN}, \sigma_{y}=289 \mathrm{~N} / \mathrm{mm}^{2}\right)$

(b) Type-II(き裂あり-下フランジのみ)
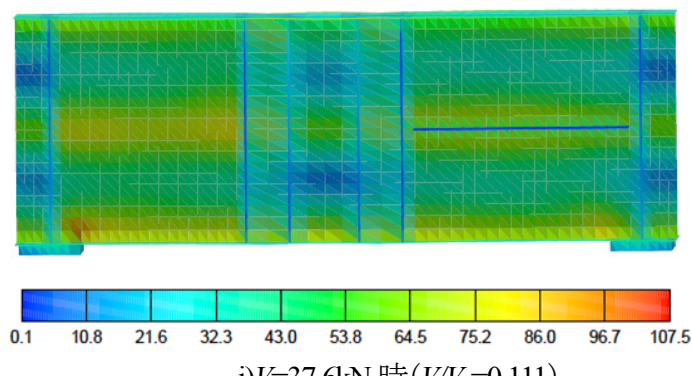

i) $V=37.6 \mathrm{kN}$ 時 $\left(V / V_{u}=0.111\right)$
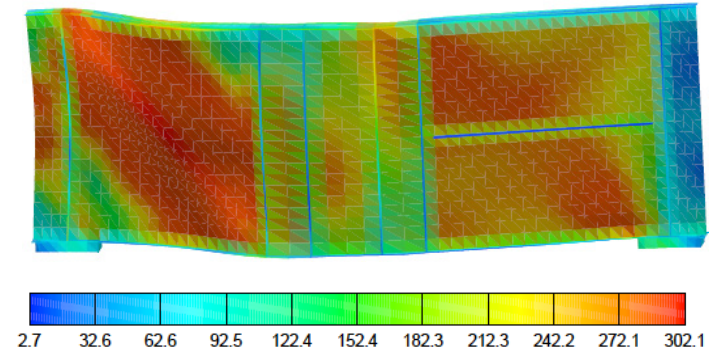

ii)終局状態 $\left(V_{u}=338.3 \mathrm{kN}, \sigma_{y}=289 \mathrm{~N} / \mathrm{mm}^{2}\right)$

(c) Type-III (き裂ありー下フランジと腹板パネル 20mm)

図-20 腹板の等価応力レベルゾーンと変形状態

以上のように, 座屈せん断力, 終局せん断力, および 座屈崩壊モードが実験結果と解析結果とで良好に一致し ていると判断できることから，これらの検討にあたって 本解析モデルは有効であると考えられる.

次に, 供試体 Type-I, Type-II, および Type-III の解析に よる腹板パネルの等価応力 $\bar{\sigma}$ のコンター図(式(3c)) と変 形状態とを図-20に示す. 赤い部分は, von Mises の降伏 条件による相当応力の降伏領域を示している. なお, 作 用せん断力が $37.6 \mathrm{kN}$ は, 腹板が弾性範囲内にあるせん断 カレベルである.

$$
\bar{\sigma}=\sqrt{\sigma_{x}^{2}-\sigma_{x} \sigma_{y}+\sigma_{y}^{2}+3 \tau^{2}}
$$

解析における座屈崩壊モードでは，き裂のない Type-I の場合, 荷重初期段階において腹板パネルのソールプレ 一ト溶接部周辺に集中的に発生した応力が次第にパネル 対角方向に広がり，斜張力場を形成して崩壊に至ってい ることがわかる.

下フランジおよび腹板にき裂を有する Type-II および Type-III の場合, 荷重初期段階においてき裂䧓辺に集中的 に発生した応力は下フランジに沿うように横方向に広が り, 再配分される. その後, Type-I のモデルと同様に斜 
張力場を形成して崩壊に至っている，いずれも，実験結 果と同様の座屈崩壊のモードが解析において再現できて いることがわかる.

せん断座屈発生前の腹板のせん断ひずみ分布の理論 9) 值を，せん断力 $50 \mathrm{kN}$ 時の場合を例に，腹板パネルの断 面(1)から(5)までにおいて図-21 に示す。なお，断面(1)は き裂を含む直上の断面であり，これを基準に両側近傍に 断面(4)（ソールプレート側）と断面(5)を設定した. いず れの図にもき裂がない場合，すなわち Type-I における腹 板のせん断ひずみの理論值を参考に示している.

き裂がない Type-I では，載荷点に近い断面(3)において 腹板パネル圧縮側のせん断ひずみが理論值に比べ若干大 きくなっている．き裂がない Type-I とき裂がある Type-II および Type-III とのせん断ひずみ分布の比較では，き裂 近傍の断面である断面(1), (4)および(5)のき裂近傍部にお
いて大きな違いが表れている. Type-II と Type-III との違 いでは, Type-III のき裂位置近傍において（断面(1)および 断面(5)）せん断ひずタが大きくなっているのがわかる. これは，き裂が下フランジおよび复板の高さ $20 \mathrm{~mm}$ まで 存在することでせん断応力が集中する場所が変化し，せ ん断ひずタに変化が現れたと考えられる.

この大きなせん断ひずみについては，き裂の大小にも 関係しており,下フランジのみにき裂がある Type-II では, 腹板最下縁のせん断ひずみが大きくなっている. 一方, 腹板に 20mm のき裂がある Type-III では，Type-II と異な り，最下縁ではなく，その上方のせん断ひずみが大きく なっている。

このように，き裂の存在によりき裂付近の腹板パネル のせん断ひずみ分布が大きく影響を受けていることがわ かる.

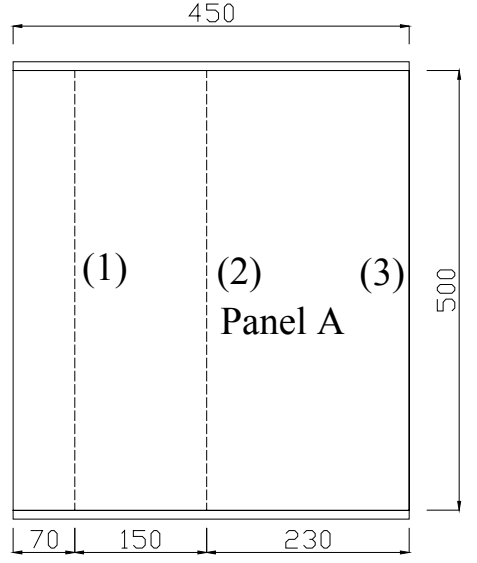

(a) Type-I の着目断面

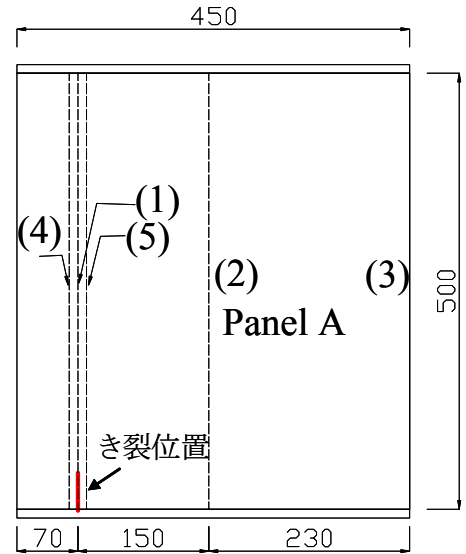

(b) Type-II, Type-III $の$ 着目断面

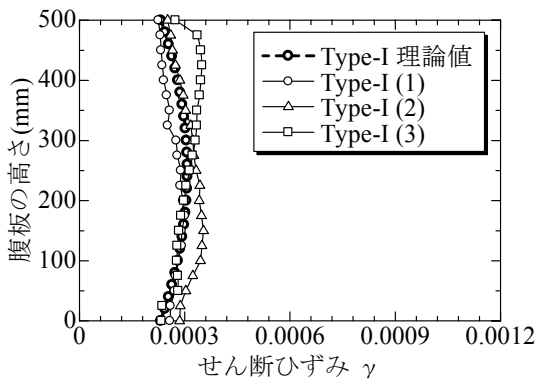

i) Type-I

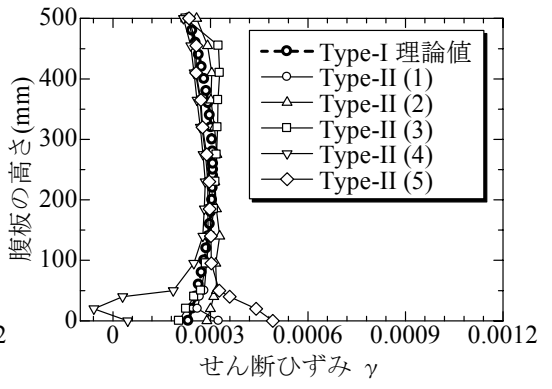

ii) Type-II

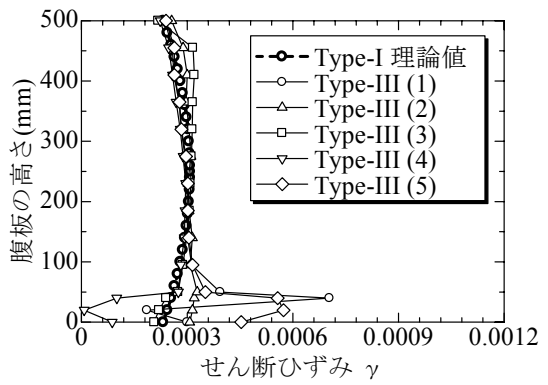

iii) Type-III

(c) せん断力 $50 \mathrm{kN}$

図-21＼cjkstart腹板のせん断ひずみの変化

表-9 解析ケースの内訳とき裂パターン

\begin{tabular}{|c|c|c|c|c|c|}
\hline \multirow{2}{*}{ 解析モデル } & \multicolumn{5}{|c|}{ き裂位置および長さ } \\
\cline { 2 - 6 } & 腹板 & き裂長さ & 下フランジ & き裂長さ & き裂長さ/腹板高さ \\
\hline Type-III-40 & き裂あり & $40 \mathrm{~mm}$ & き裂あり & 全域 $(215 \mathrm{~mm})$ & 0.08 \\
\hline Type-III-60 & き裂あり & $60 \mathrm{~mm}$ & き裂あり & 全域 $(215 \mathrm{~mm})$ & 0.12 \\
\hline Type-III-80 & き裂あり & $80 \mathrm{~mm}$ & き裂あり & 全域 $(215 \mathrm{~mm})$ & 0.16 \\
\hline Type-III-100 & き裂あり & $100 \mathrm{~mm}$ & き裂あり & 全域 $(215 \mathrm{~mm})$ & 0.20 \\
\hline
\end{tabular}




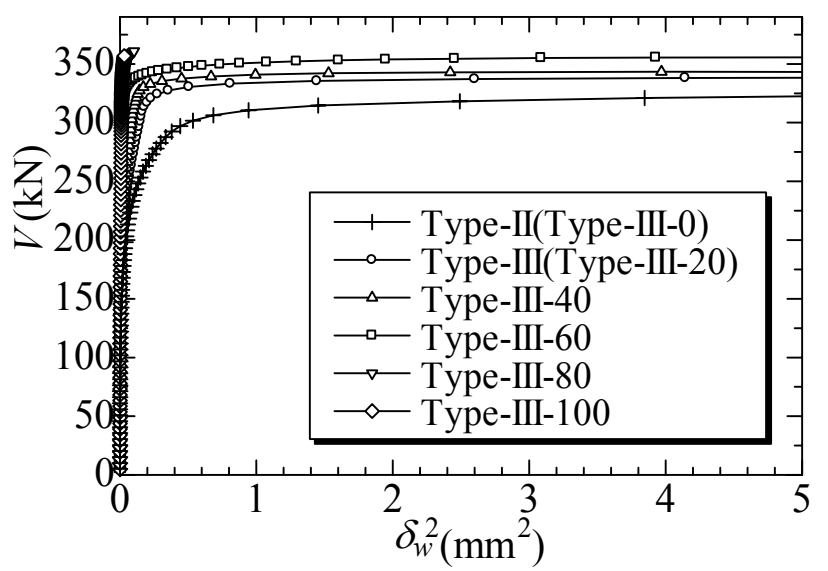

図-22 き裂長さをパレメータとした作用せん断力と面外変位との関係 $\left(V-\delta_{w}{ }^{2}\right)$

表-10 解析結果のまとめ

\begin{tabular}{|c|c|c|c|}
\hline 解析モデル & 座屈せん断力 $(\mathrm{kN})$ & 終局せん断力 $(\mathrm{kN})$ & 終局せん断力時の変形量 $(\mathrm{mm})$ \\
\hline Type-III-40 & 289.5 & 343.3 & 1.99 \\
\hline Type-III-60 & 277.6 & 355.7 & 1.75 \\
\hline Type-III-80 & 274.2 & 351.9 & 0.37 \\
\hline Type-III-100 & 257.4 & 341.3 & 0.13 \\
\hline Type-II(Type-III-0) & 263.3 & 326.7 & 3.78 \\
\hline Type-III(Type-III-20) & 291.9 & 338.3 & 2.04 \\
\hline
\end{tabular}

\section{（3）き裂長さを変化させたパラメトリック解析}

き裂長さの大小による座屈せん断力および終局せん断 力の変化を調べるために, 実験供試体 Type-III を基本とし た解析モデルに対し，腹板パネル内におけるき裂長さを 変化させた 4 つの解析ケースを設定した.

設定した解析ケースの内訳を表-9に示す，き裂は，き 裂進展の影響を評価するために, 腹板上方に垂直に進展 した状態を想定した。

解析により得られた各解析ケースの作用せん断力と腹 板パネルの最大面外変位との関係 $\left(V-\delta_{w}{ }^{2}\right)$ を図-22 に, 各解析ケースの図-23 (a) に示す節点 1 から節点 11 におけ る腹板の面外変位 $\left(V-\delta_{w}{ }^{2}\right)$ の分布を図-23(b) から (f) に示 す.また，解析結果のまとめを表-10に示す.

表-10 において, 終局せん断力時の変位量としては腹 板の最大面外変位量を表している. 座屈せん断力は, 図 -10 と同様に, 腹板の最大面外変位による $V-\delta_{w}{ }^{2}$ 曲線の傾 きが初期勾配から大きく変化する点とした. 図-22 より， 腹板の面外変位はき裂長さの増大に伴い減少し, Type-III-100 では終局せん断力時の腹板の変位は最も少な くなっている.

表-10より，座屈せん断力は，き裂が 40mm 近くまで は増加し, その後, 低下する傾向が見られるが, $100 \mathrm{~mm}$ の場合も, 0mm の場合(Type-II) と比較して, 遜色のない 98\%の值となっている. 終局せん断力は，き裂が $60 \mathrm{~mm}$ 近くまでは増加し, その後, 低下寸る傾向が見られるが, $100 \mathrm{~mm}$ の場合でも, 0mm の場合(Type-II)より, 高い值(1.04 倍)となっている.

腹板パネルの面外変形については, 図-23より,き裂長 さが大きくなるにしたがって, 腹板パネル中央の面外変
位(節点 5,6)が減少し, 相対的に, 腹板パネル上方(節点 8,9) の面外変位が大きくなっていることがわかる．また，腹 板パネルにおける面外変位の絶対量は，き裂が大きくな るにつれて減少していると言える.

このように腹板パネルのき裂が桁高の $1 / 6$ 程度までは, 腹板パネルにき裂のない場合に比べて座屈せん断力は高 い值を示し，それ以上のき裂を有する場合でも，大きな 低下が見られないことが判明した。

つまり，座屈せん断力は，き裂の存在の影響を受け， き裂長の大小によって荷重伝達メカニズムが変化する. その結果, 座屈せん断力が変化すると考えられる. 特に, き裂長さが $80 \mathrm{~mm}$ を超える場合とそうでない場合に面外 変位の分布性状が異なっている. せん断座屈が支配的な 場合とき裂先端の降伏による断面降伏が支配的な場合の 二つのメカニズムが想定される. また, 終局せん断力も, き裂の存在の影響を受け, き裂長の大小によって荷重伝 達メカニズムが変化し, その結果, 終局せん断力も変化 すると考えられる. 本研究の範囲内であれば，き裂が存 在しても終局せん断力を低下させることはなく，斜張力 場の形成に伴い，腹板パネルはトラス構造のような機構 で抵抗し，き裂が終局せん断力を低下させないものと推 察される. なお，き裂を有する部材(本試験体)の塑性変形 能力(終局せん断力時の変形量)に注目すると, Type-II に対 し, Type-III-100 はその塑性変形能力が 1/34 以下となり, 大きく低下寸ることが明らかとなった．したがって，耐 荷力の低下は見られないものの, 変形能力は大きく低下 するため, 而震性能を確保する観点から, き裂の存在は 注意を要する. 


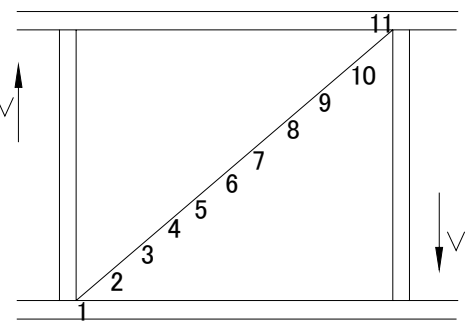

(a) 腹板面外変位の計測位置

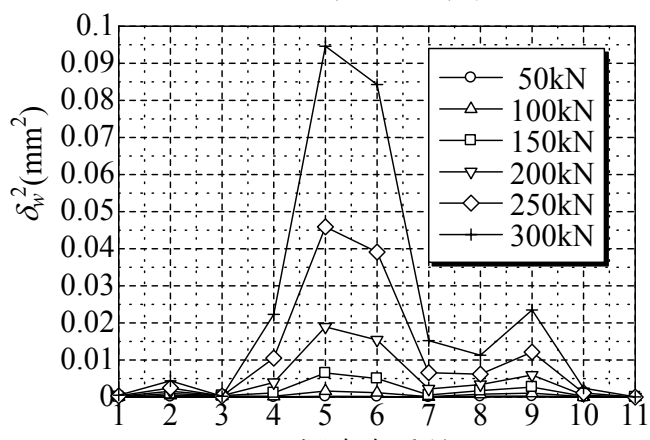

測定点番号

(c) Type-III-40

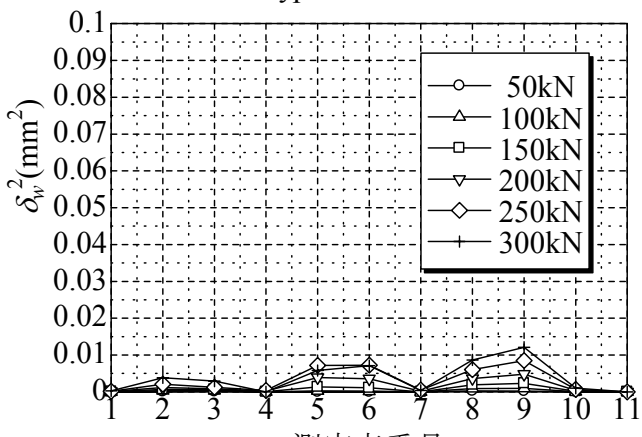

測定点番号

(e) Type-III- 80

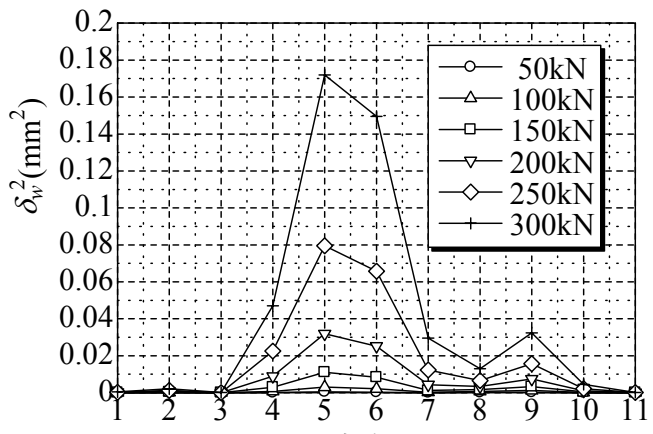

測定点番号

(b) Type-III

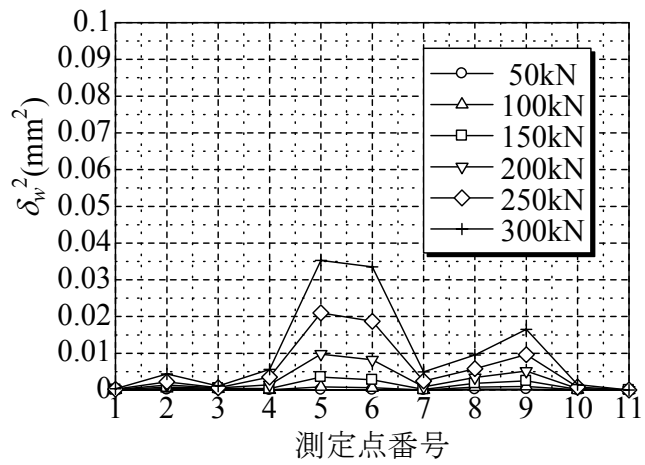

(d) Type-III-60

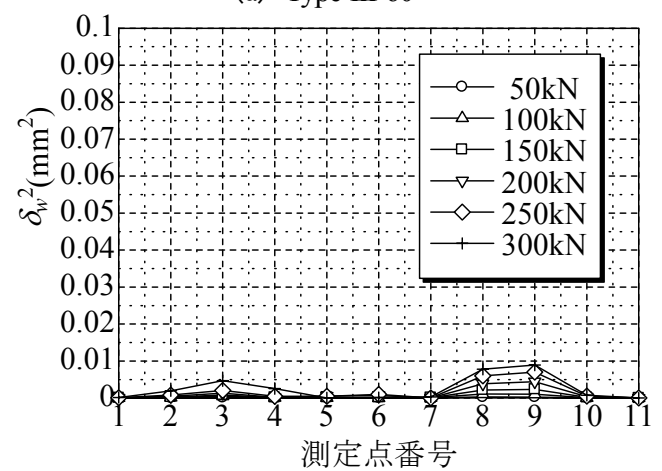

(f) Type-III-100

図-23 腹板の面外変位 $\delta_{w}^{2}\left(\mathrm{~mm}^{2}\right)$ 分布の変化

\section{5. まとめ}

鋼析橋の支承部において，ソールプレート溶接部周辺 に発生する疲労き裂が桁端部腹板パネルのせん断而荷力 に与える影響を，下フランジおよび腹板パネルに人工的 に模擬き裂を入れた供試体を用いた載荷実験および数值 解析を行い，検討した．ただし，模擬き裂が進展しない こと，およびき裂方向が限定されるなど基礎的な検討と なっている. 以下に, 本研究により得られた主な成果を 示す.

(1) 腹板の面外変位に基づいて算出した座屈せん断力に 着目すると, フランジのみにき裂を有するモデルのそ れは, き裂を有さない健全なモデルに比べあまり変化 しなかった. 一方，フランジおよび腹板にき裂を有す る場合には，健全なモデルに比べ，き裂長さが腹板の 高さのおよそ $1 / 6$ までは座屈せん断力が上昇し，それ
以上のき裂の場合は減少する傾向にあることがわか った. ただし，その低下量は小さく，フランジのみに き裂を有するモデルのそれとほとんど変わらない. フ ランジおよび腹板にき裂を有する場合に座屈せん断 力の上昇は，腹板パネルにき裂がある場合，き裂進展 で座屈波形の連続性がなくなり実質的に下フランジ 側の腹板パネル長が短くなり, 楕円形の座屈波形の幅 が小さくなるとともに上方に移動するためである.

(2) 一方，終局せん断力は，き裂の存在に伴い，き裂が 60mm 近くまでは増加の傾向にあり, その後, わずか に低下するものの, その低下量は極めて少ないことが わかった. 疲労き裂が下フランジを貫通して腹板パネ ルにまで至った場合であっても, せん断座屈後の斜張 力場が上方に移動し, その幅が小さくなる傾向は認め られるものの，桁端部の終局せん断力は低下せず，十 分な残存せん断而荷力を有していることを明らかに 
した. 終局せん断力はき裂長さの影響を受け, き裂の 大小によってその荷重伝達メカニズムが異なる.

（3）き裂が存在する場合の座屈せん断力は, き裂の存在を 考慮した腹板パネルのアスペクト比を用いた幅厚比 パラメータにより良好な評価が可能であることがわ かった. しかしながら，せん断力を受けるプレートガ 一ダーの終局せん断力については, 腹板パネルが斜張 力場になり, その後, 上下フランジと垂直補岡材とか らなるラーメン構造が塑性崩壊モードに至るまでの 強度を考慮することが必要であることがわかった。

今後は，支承の支持条件(古い支承では回転固定になっ ている.)，き裂の進展方向，き裂長さなどが斜張力場の形 成に影響を与える場合などについても検討するとともに， より現実的なき裂を導入した実験・解析を行う必要があ る.

謝辞 : 本研究は, 科学研究補助金:基礎研究(A)(1)「既設鋼 道路橋の抵抗度診断技術とレトロフィッティング技術の 開発に関する研究(代表:三木千壽)」の一環として行った ものである.

\section{参考文献}

1) 三木千寿, 館石和雄, 徳納 優, 名取 暢 : プレートガーダ
ーソールプレート部の局部応力と疲労, 土木学会第 47 回年 次学術講演会概要集, pp. 440-441, 1992.

2) 西川和廣, 村越 潤, 広瀬隆宏 : 鋼林支承ソールプレート溶 接部の疲労に関する検討一損傷事例と補修・補強方法に関す る調査結果一，土木技術資料，Vol.36-1，pp.60-67，1994.

3) 西川和廣, 村越 潤, 広瀬隆宏 : 鋼林支承ソールプレート溶 接部の疲労に関する検討一模型桁の静的載荷実験に基づく 桁端部の応力と細部構造に関する検討一, 土木技術資料, Vol.35-7, pp. 51-58, 1993.

4) 渡辺真至, 西 浩嗣, 谷倉 泉, 海野清司 : 鋼桁支承ソールプ レート溶接部の疲労損傷と補強効果, 土木学会第 51 回年次 学術講演会概要集, pp.778-779, 1996.

5) 土木学会鋼構造委員会 : 鋼構造シリーズ 2, 座屈設計ガイド ライン, pp.193-225, 1987.10.

6) 日本道路協会 : 道路橋示方書・同解説，I 共通編，および II 鋼橋編，丸善，2002.

7) 阪神高速道路公団(旧) : 曲線桁橋腹板のせん断而渮力に関す る研究, pp.107-112, 1982.3.

8) USSP ユーザーズ・マニュアル，Ver.5.0，JIPテクノサイエン ス(株), 2001.3.

9) 中井 博, 北田 俊行 : 鋼橋設計の基礎，共立出版. 1992.

(2008. 1. 21 受付)

\section{FUNDAMENTAL STUDY ON ULTIMATE STRENGTH OF PLATE GIRDER ENDS WITH CRACKS AROUND SOLE PLATES SUBJECTED TO PREDOMINANT SHEAR FORCE}

\section{In-Ho KIM, Takashi YAMAGUCHI, Toshiyuki KITADA, Tomoaki NAKAMURA}

The residual load carrying capacity of a plate girder end panel with a fatigue crack around the sole plate subjected to predominant shear force is investigated experimentally and analytically in this study. First of all, the experiment is carried out using 3 types of the test specimens with cracks of different length. Then, elasto-plastic and finite displacement analysis is conducted varying the crack length for investigating the influence of the crack length on the residual load carrying capacity. It can be found through the experiment and analysis that the load carrying capacity of the plate girder end panel with a crack passing throughout the cross section of the lower flange plate and penetrating the lower web part shorter than 1/6 times the web height does not decrease significantly compared with that of the intact plate girder end panel without crack. Finally it is suggested that the residual shear buckling capacity of the plate girder end panel with the crack can be approximately and accurately evaluated by using the plate slenderness parameter $R_{\tau w}$ using the reduced aspect ratio considering the location of the crack. 